\title{
Review of Coelostoma of the Indian subcontinent (Coleoptera: Hydrophilidae) Part 1: Coelostoma s. str. and Holocoelostoma
}

\author{
Sayali D. SHETH ${ }^{1}$, Hemant V. GHATE ${ }^{2} \&$ Martin FIKÁČEK ${ }^{3,{ }^{*}}$ \\ ${ }^{1}$ Annasaheb Kulkarni Department of Biodiversity, Abasaheb Garware College, Pune, India. \\ ${ }^{2}$ Department of Zoology, Modern College, Shivajinagar, Pune, India. \\ ${ }^{3}$ Department of Entomology, National Museum, Cirkusová 1740, CZ-19300, Praha 9 - Horní \\ Počernice, Czech Republic \& Department of Zoology, Faculty of Science, Charles University, \\ Viničná 7, CZ-12844, Praha 2, Czech Republic. \\ "Corresponding author: mfikacek@gmail.com \\ ${ }^{1}$ Email: saylisheth@gmail.com \\ ${ }^{2}$ Email: hemantghate@gmail.com \\ ${ }^{1}$ urn:1sid:zoobank.org:author:1F5AD99F-7DDE-455A-9DA0-6E9C263F0A5E
${ }^{2}$ urn:1sid:zoobank.org:author:26ED55BA-F5FF-4F89-98E8-348B506A4CCB
${ }^{3}$ urn:1sid:zoobank.org:author:E1A02744-41A2-4B9C-A127-B78F0D812637
}

\begin{abstract}
Species of the genus Coelostoma Brulle, 1935 belonging to the subgenera Coelostoma s. str. and Holocoelostoma Mouchamps, 1958 from the Indian subcontinent are revised. Six species of Coelostoma s. str. and two species of Holocoelostoma are recognized, of which two are described as new: C. (Coelostoma) lyratum sp. nov. (India: Maharashtra) and C. (Coelostoma) nostocinum sp. nov. (India: Maharashtra, Goa, Karnataka, Kerala). Coelostoma (Coelostoma) fallaciosum Orchymont, 1936 and C. (Coelostoma) vividum Orchymont, 1936 were recorded for the first time from India and Bangladesh, respectively. Lectotypes are designated for C. aeneolum Régimbart, 1903 and Hydrobius stultus Walker, 1858. The previously confusing situation with Coelostoma (Holocoelostoma) stultum (Walker, 1858) and C. (Holocoelostoma) bhutanicum Jayaswal, 1972 is clarified based on new material of both species from India. Coelostoma sulcatum $\mathrm{Pu}, 1963$ from China is removed from the synonymy of C. stultum and considered as a likely synonym of $C$. bhutanicum, a status which needs to be confirmed by a detailed study of type specimens. All species are (re)described and illustrated. Diagnosis of the subgenera of Coelostoma are modified in order to accommodate the species of the Indian subcontinent, resulting in narrowing down the concept of Coelostoma s. str. and widening the concept of Lachnocoelostoma Mouchamps, 1958.
\end{abstract}

Keywords. Hydrophiloidea, Oriental Region, new species, lectotype designation, biodiversity shortfalls.

Sheth S.D., Ghate H.V. \& Fikáček M. 2020. Review of Coelostoma of the Indian subcontinent (Coleoptera: Hydrophilidae) Part 1: Coelostoma s. str. and Holocoelostoma. European Journal of Taxonomy 690: 1-32. https://doi.org/10.5852/ejt.2020.690 


\section{Introduction}

Hydrophilidae Latreille, 1802 is a major group of water beetles with about 3000 described species classified in 6 subfamilies and 12 tribes (Short \& Fikáček 2013). This group is ancestrally aquatic, but one of its lineages colonized terrestrial habitats ca 175 million years ago (Bloom et al. 2014). This lineage gave rise to a diverse fauna currently classified in the subfamilies Sphaeridiinae Latreille, 1802 and Cylominae Zaitzev, 1908 (Toussaint \& Short 2018). A few lineages of these secondarily terrestrial groups returned to water. This is the case with Cylomissus Broun, 1903 and Anticura Spangler, 1979 (Minoshima et al. 2015) and larvae of the otherwise flower inhabiting Rygmodus White, 1846 (Minoshima et al. 2018) in Cylominae, a few lineages of the genus Cercyon Leach, 1817 (Arriaga-Varela, unpubl. data) and the whole genus Coelostoma Brullé, 1835 in Sphaeridiinae.

The coelostomatine genus Coelostoma is mainly distributed in the Afrotropical and Oriental regions, with a few species also present in the Palearctic and Australian regions (Hansen 1999). About 120 species have been described in this genus, with the highest known diversity occurring in China (Jia et al. 2014, 2017, 2019). All known species with available biological data are aquatic, occurring in habitats ranging from shallow ponds to horizontal and vertical wet cliffs (Jia et al. 2019).

The genus is characterised by broadly oval and dorsally convex body, dark brown to black colour, loosely arranged antennal club, prosternum bulging medially and dentiform anteriorly, mesoventrite with an elevated arrowhead-shaped structure in the middle, metaventrite with strongly elevated median portion, anteriorly projecting between mesocoxae and abutting mesoventral elevation, the first metatarsomere longer than second tarsomere, elytra with sutural stria and usually without serial punctures (with few exceptions), and the first abdominal ventrite not carinate medially (with a few exceptions; Hansen 1991; Jia et al. 2014).

The Asian fauna of Coelostoma is rather species-rich, but the lack of modern revisions prevents reliable identification. However, the fauna was recently revised in China (Jia et al. 2014, 2017, 2019), Taiwan (Liu et al. 2020) and Japan (Hayashi 2008). These studies provided good quality illustrations of genital characters crucial for the species identification and recognized many previously undescribed species. Other parts of tropical and subtropical Asia remain unrevised, including the Indian subcontinent, a region characterized by high species diversity and endemism (Myers et al. 2000; Mittermeier et al. 2005). So far, sixteen species of Coelostoma have been recorded from the Indian subcontinent (Walker 1858; Orchymont 1923a, 1923b, 1928, 1936; Mouchamps 1958; Jayaswal 1972; Hebauer 2000, 2002), but a detailed taxonomic revision is wanting, and the status of many of these species remains unclear (Linnean shortfall; Hortal et al. 2015). Thus, the aim of this revision is to overcome Linnean and Wallacean shortfalls (as defined by Hortal et al. 2015) by providing basic information about the diversity and distribution of species and to provide taxonomic keys, descriptions and illustrations allowing an easy identification of Coelostoma species.

For practical purposes, we divided the revision into two parts. Here we present the revision of two subgenera: Coelostoma s. str. Brullé, 1835 and Holocoelostoma Mouchamps, 1958. The revision of the more diverse subgenus Lachnocoelostoma Mouchamps, 1958 from India will be presented later. Here, we describe two new species from India, provide new distribution records of all known species from the Indian subcontinent and illustrate the characters of all of them.

\section{Material and methods}

\section{Study area}

The Indian Peninsula is located north of the Equator including India, Pakistan, Sri Lanka, Nepal, Bhutan and Bangladesh (Fig. 1). This subcontinent is bounded by the geologically unstable Himalayan 
Mountains in the north, because of which the region experiences tropical monsoon. Additionally, the subcontinent is lined by shoreline on western, eastern and southern sides. Diverse ecological conditions ranging from dry deserts, evergreen forests to temperate and alpine environments exist in the region. Furthermore, the Western and Eastern Ghats form the edges of the geologically stable Peninsular Plateau of the subcontinent, which was one of the parts of the ancient Gondwana. All these physical features contribute to gradients of interacting climatic conditions of precipitation, altitude and temperature on the subcontinent (Mani 1974).

\section{Specimen examination}

The genitalia were dissected from water-relaxed specimens and examined on temporary glycerine slides or in permanent mounts in Euparal, in both cases without a cover glass. Photographs of glycerine mounted genitalia were taken with a Canon D1100 digital camera attached to an Olympus BX41 compound microscope. Photographs of external morphology were taken using a Canon EOS 550D digital camera with an attached Canon MP-E65 mm f/2.8 $1-5 \times$ macro lens. We standardized

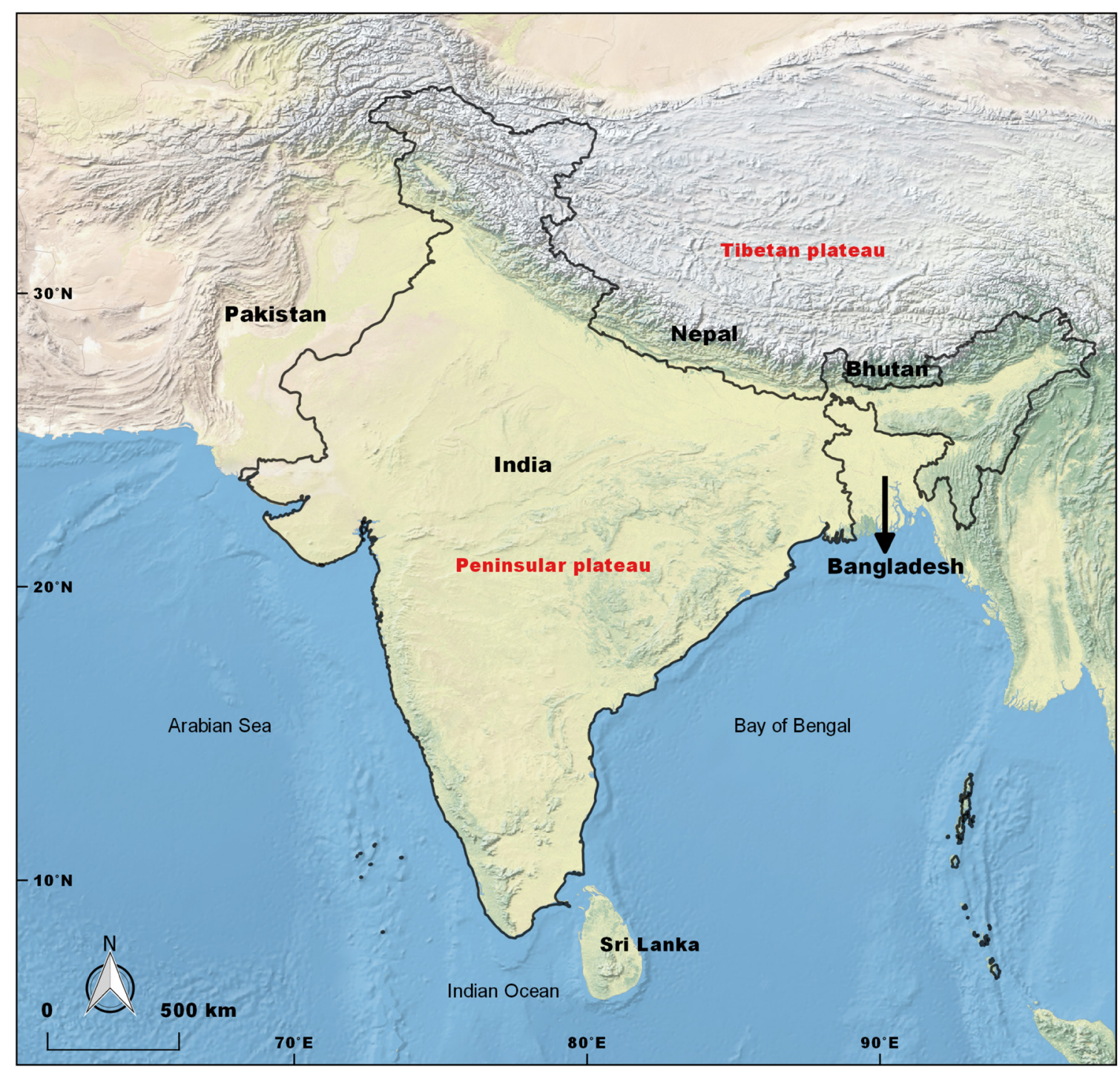

Fig. 1. Overview of the Indian subcontinent and its main geographic features. 
the photographic documentation provided for each species to include principal characters important for the reliable identification of all Indian Coelostoma (including the subgenus Lachnocoelostoma not treated here). For this reason, the plates even include characters which seem invariable (e.g., dorsal punctation) but are crucial for diagnosing the species treated here from some Indian species of Lachnocoelostoma. Original unedited photographs are available in the Zenodo archive under https://doi.org/10.5281/zenodo.3949349. For details of the methods used, see Sheth et al. (2018) and Fikáček \& Liu (2019). Geographical coordinates were obtained from GoogleMaps and GoogleEarth ${ }^{\odot}$ in case they are not listed on the labels. Incorrect coordinates provided on labels were rectified, based on locality data interpreted from the label and additional data (e.g., altitude) was added in some cases; all these data that we added are placed in brackets. Maps were constructed in QGIS (ver. 2.18.5, https://qgis.org/downloads/).

\section{Review of published data}

We have reviewed the literature referring to the occurrence of Coelostoma species on the Indian subcontinent. These publications are listed in the synonymy section, and faunistic data from corresponding publications are summarized under Published records. Publications with records outside of the Indian subcontinent are not listed in these sections.

\section{Depositories}

Examined specimens (Supplementary file SM.01) are deposited in the following collections:

BMNH $=$ The Natural History Museum, London, UK

IRSNB = Institute royal des Sciences naturelles, Brussels, Belgium

IZCAS = Chinese Academy of Sciences, Institute of Zoology, Beijing, China

MNHN = Muséum national d'histoire naturelle, Paris, France

NCBS $=$ National Centre for Biological Sciences, Bengaluru, India

NHMW $=$ Naturhistorisches Museum, Vienna, Austria

NMPC = National Museum, Prague, Czech Republic

SMNS $=$ State Museum of Natural History, Stuttgart, Germany

UASB = University of Agricultural Sciences, Bengaluru, India

ZSI = Zoological Survey of India, Western Region, Pune, Maharashtra, India

\section{Results}

\section{Taxonomy}

Order Coleoptera Linnaeus, 1758

Superfamily Hydrophiloidea Latreille, 1802

Family Hydrophilidae Latreille, 1802

Subfamily Sphaeridiinae Latreille, 1802

Tribe Coelostomatini Heyden, 1891

Genus Coelostoma Brullé, 1835

\section{Subgenera of Coelostoma}

Mouchamps (1958) defined four subgenera of Coelostoma on the basis of the combination of three characters: (1) the pubescence on the mesofemora (with or without dense pubescence), (2) morphology of the abdominal apex (with or without stout setae) and (3) the morphology of the tarsal claws (simple or bifid, the latter in the subgenus Hammacoelostoma Mouchamps, 1958, not occurring in the Indian subcontinent). These characters have since then been successfully used to place all described species in 
Table 1. Characters defining the subgenera of Coelostoma Brullé, 1935 as used in this study. Only the subgenera Lachnocoelostoma Mouchamps, 1958, Coelostoma s. str. and Holocoelostoma Mouchamps, 1958 occur in the Indian subcontinent.

\begin{tabular}{lllll}
\hline Character & Lachnocoelostoma & Coelostoma s. str. & Holocoelostoma & Hammacoelostoma \\
\hline Empodial setae & fine, hair-like & fine, hair-like & fine, hair-like & $\begin{array}{l}\text { thick and strongly } \\
\text { sclerotized (resembling } \\
\text { an additional pair } \\
\text { of massive spines } \\
\text { between tarsal claws) }\end{array}$ \\
\hline & $\begin{array}{l}\text { with dense pubescence } \\
\text { present on the whole } \\
\text { surface or at least in } \\
\text { the anterior part of } \\
\text { the mesofemur (i.e., } \\
\text { mesofemur can be } \\
\text { largely bare in some } \\
\text { species!) }\end{array}$ & $\begin{array}{l}\text { completely } \\
\text { without dense } \\
\text { long pubescence, } \\
\text { only with sparsely } \\
\text { arranged short } \\
\text { setae }\end{array}$ & $\begin{array}{l}\text { completely } \\
\text { without dense } \\
\text { long pubescence, } \\
\text { only with sparsely } \\
\text { arranged short } \\
\text { setae }\end{array}$ & $\begin{array}{l}\text { with dense pubescence } \\
\text { thirds }\end{array}$ \\
\hline $\begin{array}{l}\text { Abdominal anterior two } \\
\text { ventrite 1 }\end{array}$ & $\begin{array}{l}\text { with or without } \\
\text { median carina }\end{array}$ & $\begin{array}{l}\text { never with median } \\
\text { carina }\end{array}$ & $\begin{array}{l}\text { never with median } \\
\text { carina }\end{array}$ & without median carina \\
\hline $\begin{array}{l}\text { Abdominal apex: } \\
\text { stout setae }\end{array}$ & $\begin{array}{l}\text { usually present, absent } \\
\text { in few species }\end{array}$ & always absent & always present & absent or present \\
\hline $\begin{array}{l}\text { Abdominal apex: } \\
\text { emargination }\end{array}$ & present or absent & always absent & present or absent & absent \\
\hline
\end{tabular}

subgenera (e.g., Hansen 1999). Characters (1) and (2), relevant for recognizing the subgenera occurring in India, were illustrated by Jia et al. (2014).

The study of the Indian Coelostoma revealed that the morphological diversity within the genus is much higher than expected, especially in the subgenus Lachnocoelostoma, with some species not fitting the combination of characters used by Mouchamps (1958). To deal with this problem, we are adapting the definition of the subgenera of Coelostoma in the way specified in Table 1, using five characters. The re-examination of C. (Hammacoelostoma) afflatum Knisch, 1922 revealed that the additional strongly sclerotized projections between the tarsal claws are in fact modified empodial setae, and not basal projections of the claws as suggested by Mouchamps (1958). Our concept narrows down the definition of Coelostoma s. str. and significantly widens the concept of Lachnocoelostoma. Reasons for that will be demonstrated in detail in the review of Indian Lachnocoelostoma (Sheth et al., in prep.). The atypical species of Lachnocoelostoma (i.e., those having largely bare mesofemora or abdominal apex without stout setae) always differ from the subgenera treated in this paper in the presence of the abdominal median carina. The carina is absent in all Coelostoma s. str. and in all Holocoelostoma, including all species treated in this paper.

\section{Key to Indian species of Coelostoma (s. str.)}

1. Median lobe cylindrical, uniformly wide throughout; gonopore on its very apex (Figs 2D, 6J-K) .. C. lyratum sp. nov.

- Median lobe more or less triangular, wider at the base than at the apex; gonopore subapical or basal (Fig. 2A-C, E-F) 2 
2. Apex of the median lobe narrowly spatulate, gonopore basal (Figs 2F, 8J-K). Small species (Fig. 2F) C. vividum Orchymont, 1936

- Apex of the median lobe not extremely narrow, gonopore subapical (Fig. 2A-C, E) 3

3. Median lobe very short and wide, gonopore very large (Figs $2 \mathrm{D}, 7 \mathrm{~J}-\mathrm{K}$ )

C. vitalisi Orchymont, 1923

- Median lobe in form of narrow and elongate triangle (Fig. 2A-C)

4. Median lobe much longer than its basal struts, lateral sides of the median lobe concave. Apex of paramere strongly asymmetrical, with apical tooth-like projection (Figs $2 \mathrm{C}, 4 \mathrm{~J}-\mathrm{K}$ )

C. fallaciosum Orchymont, 1936

- Median lobe only slightly longer than its struts, lateral margins of the median lobe straight. Apex of paramere more less symmetrical, without distinct tooth-like projection (Fig. 2A-B)

5. Aedeagus larger $(0.7 \mathrm{~mm})$, outer face of the paramere slightly concave in its apical third. Median lobe relatively wider at apex (Figs 2B, 5J-K)

C. nostocinum sp. nov.

- Aedeagus smaller $(0.5 \mathrm{~mm})$, outer face of the paramere continually arcuate, not concave subapically. Median lobe narrower at apex (Figs 2A, 3J-L)

C. aeneolum Régimbart, 1903

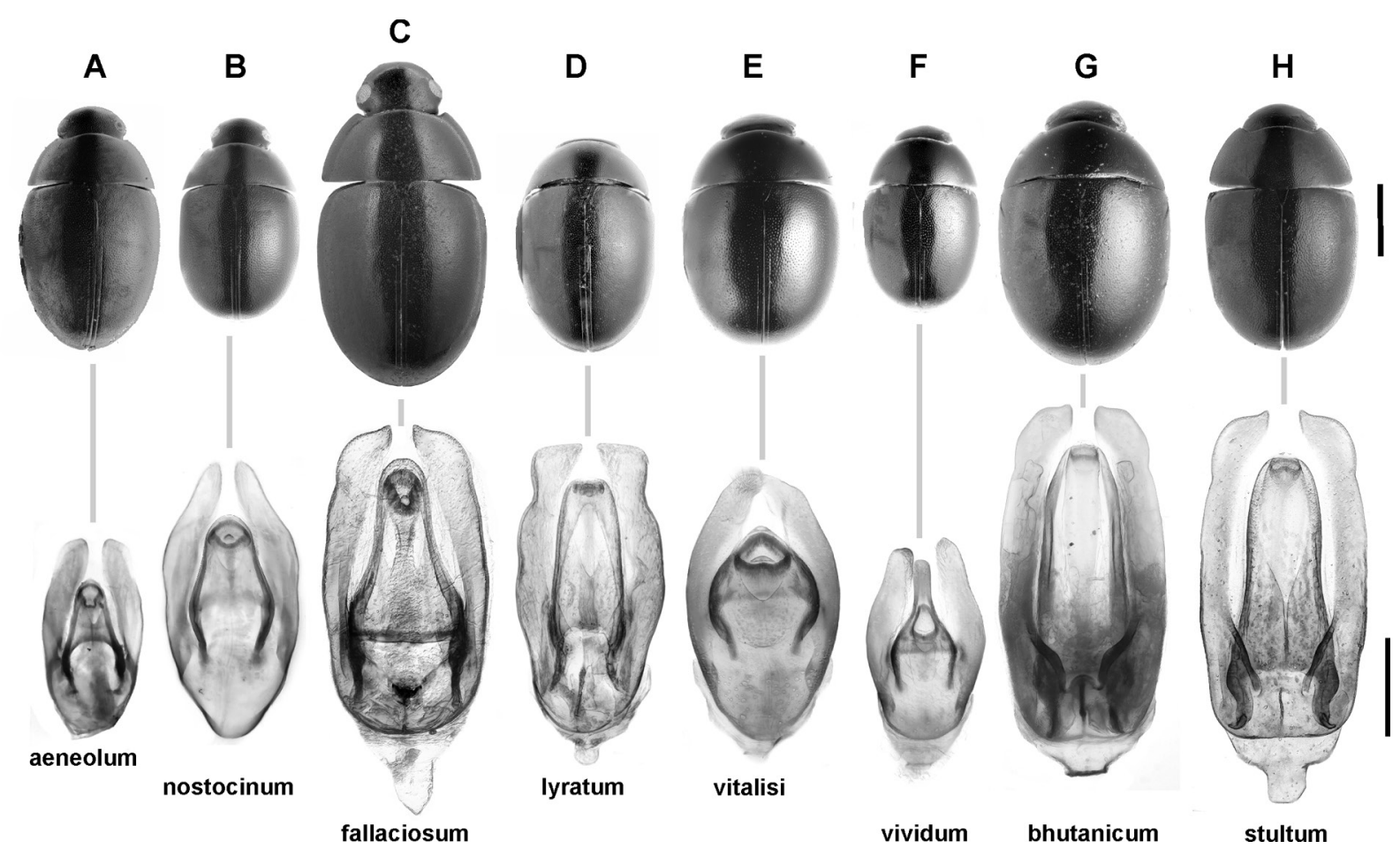

Fig. 2. Overview of Coelostoma Brullé, 1935 s. str. and Holocoelostoma Mouchamps, 1958 of the Indian subcontinent (habitus on the top, aedeagus on the bottom). - A-F. Coelostoma s. str. A. C. aeneolum Régimbart, 1903. B. C. nostocinum sp. nov. C. C. fallaciosum Orchymont, 1936. D. C. lyratum sp. nov. E. C. vitalisi Orchymont, 1923. F. C. vividum Orchymont, 1936. - G-H. Holocoelostoma. G. C. bhutanicum Jayaswal, 1972. H. C. stultum (Walker, 1858). All habitus figures and all aedeagi are to scale. Scale bars: habitus $=1 \mathrm{~mm}$; aedeagus $=0.25 \mathrm{~mm}$. 


\section{Key to Indian Coelostoma (Holocoelostoma)}

1. Median lobe of the same width from base to apical fifth, in apical fifth distinctly narrowed; lateral margins of the median lobe strongly sclerotized, median lobe spoon-like when observed slightly laterally (Figs 2G, 9J-K)

C. bhutanicum Jayaswal, 1972

- Median lobe widest at the base, gradually narrowing ca to the midlength, apical half narrowly parallel-sided, ca of the same width; lateral margins of the median lobe weakly sclerotized, median lobe not spoon-like when observed slightly laterally (Figs $2 \mathrm{H}, 10 \mathrm{~K}-\mathrm{M}$ )

C. stultum (Walker, 1858)

Coelostoma (s. str.) aeneolum Régimbart, 1903

Fig. 3A-M

Coelostoma aeneolum Régimbart, 1903: 337.

Coelostoma aeneolum - Zaitzev 1908: 403 (catalogue). — Knisch 1924: 110 (catalogue). — Orchymont 1928: 54 (catalogue).

Coelostoma (s. str.) aeneolum - Mouchamps 1958: 28 (assigned to Coelostoma s. str.). - Hansen 1999: 242 (catalogue).

\section{Differential diagnosis}

Coelostoma aeneolum resembles C. nostocinum sp. nov. and C. fallaciosum in having a narrowly triangular median lobe and the subapical gonopore. It can be distinguished from $C$. fallaciosum by parameres reaching much further than median lobe (in contrast to parameres only slightly longer than median lobe in C. fallaciosum), apex of the parameres more less symmetrically rounded (strongly asymmetrical and projecting into mesal 'tooth' in C. fallaciosum), the median lobe triangular with straight sides (sides clearly concave in C. fallaciosum) and much smaller aedeagus (ca $0.5 \mathrm{~mm}$ compared to $1.0 \mathrm{~mm}$ in C. fallaciosum). Coelostoma aeneolum is very similar to C. nostocinum sp. nov.; see under the latter species for differential characters and discussion.

\section{Material examined}

Lectotype (here designated)

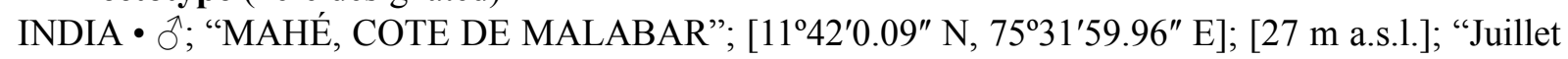
1901” [Jul. 1901]; "M. Maindron leg."; MNHN.

\section{Paralectotype}

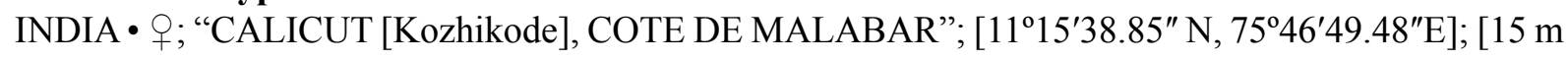
a.s.1.]; "20-25 Juin 1901” [20-25 Jun. 1901]; "M. Maindron leg."; MNHN.

The species was described based on an unspecified number of specimens deposited in MNHN. Both above specimens were found in coll. Régimbart in MNHN and their locality data agrees with the original description. We designate the male specimen here as a lectotype, to fix the identity of the species.

\section{Other material}

INDIA • 1 ơ; "Maharashtra, Bombay" [Mumbai]; [1901'3.96" N, 7251'22.09" E]; IRSNB.

\section{Redescription}

Form AND COLOUR. Body length $4.6 \mathrm{~mm}$, body width $2.6 \mathrm{~mm}$ (in both examined type specimens). Body oval in dorsal view, moderately convex in lateral view. Head black; pronotum and elytra uniformly dark 
brown with slightly paler margins; ventral surface uniformly dark brown. Tarsi pale brown. Mouthparts and antennae yellowish, antennal club brown.

HEAD. Dorsal punctation dense, consisting of simple punctures without associated ridges; trichobothria present; surface between punctures smooth. Anterior margin of clypeus arcuate. Eyes large, interocular distance ca $3.3 \times$ the width of one eye in dorsal view; eye emarginate anteriorly. Labrum moderately sclerotized, largely exposed anterior of clypeus. Antenna with 9 antennomeres, club loosely segmented. Second maxillary palpomere moderately broad.

Prothorax. Pronotum bisinuate anteriorly, anterolateral corners obtuse; posterior margin moderately bisinuate, posterolateral corners rectangular. Lateral margin with very indistinct sculpture; anterior and
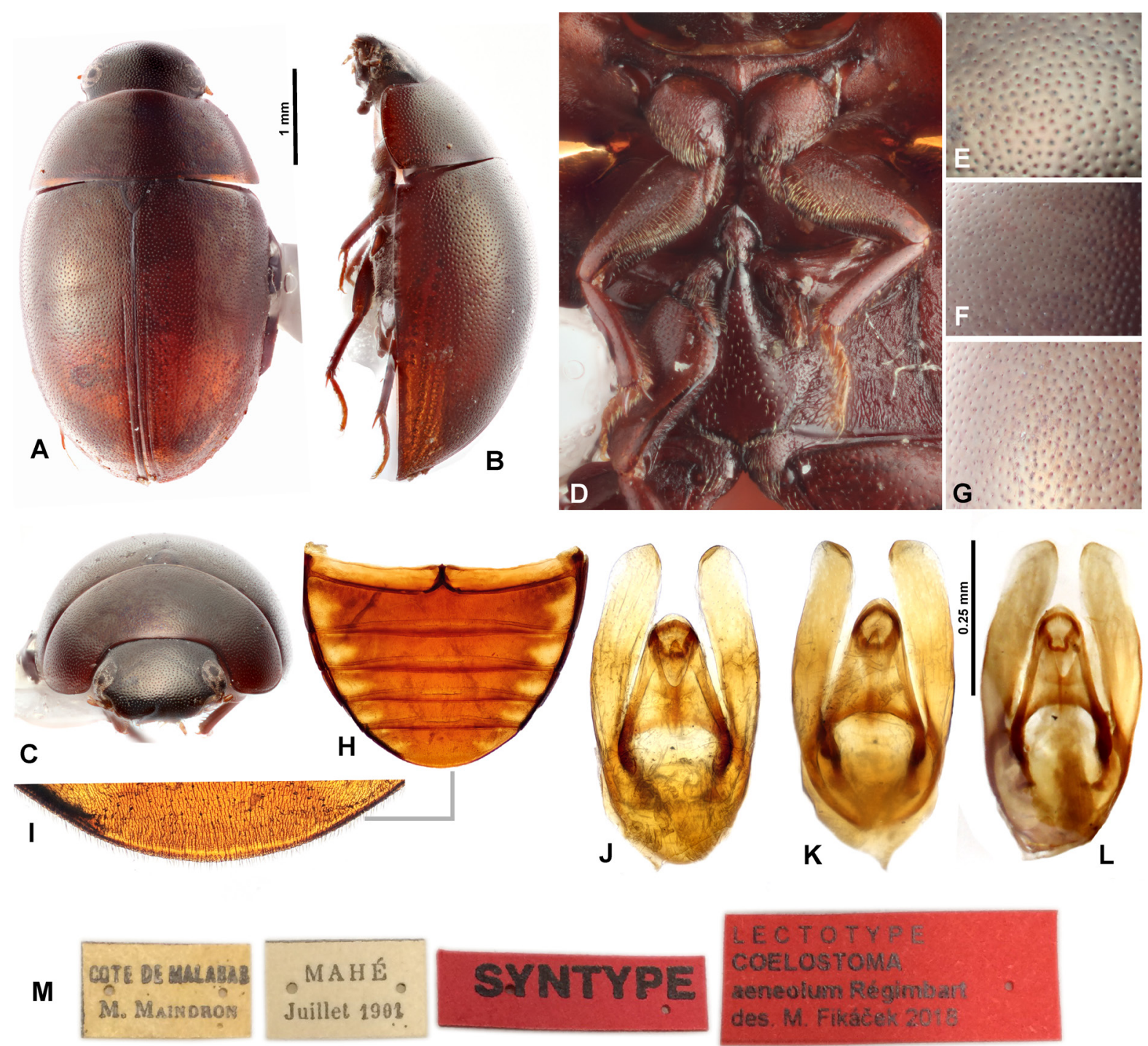

Fig. 3. Coelostoma (s. str.) aeneolum Régimbart, 1903, lectotype. A. Dorsal habitus. B. Lateral habitus. C. Frontal view. D. Thorax in ventral view. E. Dorsal punctation of head. F. Dorsal punctation of pronotum. G. Dorsal punctation of elytron. H. Abdominal ventrites. I. Detail of abdominal apex. J-L. Aedeagus. J-K. Lectotype, $\widehat{\jmath}(\mathrm{MNHN})$ (J, ventral; K, dorsal). L. Non-type specimen from Mumbai, $\widehat{\jmath}$ (IRSNB). M. Labels of the lectotype. 
lateral margins with distinct bead not extending to posterior margin. Pronotal punctation sparser and finer than on head, consisting of simple punctures without associated ridges; surface between punctures smooth. Prosternum straight on anterior margin, carinate mesally, anterior portion of carina raised, producing tooth-like process seen laterally.

Mesothorax. Elytral punctation dense and moderately coarse, consisting of punctures without transverse ridges. Series of punctures absent. Sutural stria weakly impressed, present in apical half. Mesoventral plate $1.2 \times$ as long as wide, arrowhead-shaped, bluntly pointed anteriorly, posteriorly widely attached to metaventrite.

Metathorax. Metaventrite raised medially, posterior third and anterior portion of median elevation bare, remaining median surface with sparse regular setae; lateral portions densely pubescent. Anterior metaventral process narrowly projecting between mesocoxae; posterior process bifid. Wings welldeveloped (macropterous).

Legs. Profemur with dense pubescence except in apical fifth; mesofemur and metafemur with sparsely arranged stout setae only.

AвDOMEn. All ventrites densely pubescent. First ventrite without carina. Posterior margin of last ventrite entire, without stout spines mesally.

Aedeagus (Fig. 3J-L). $0.4 \mathrm{~mm}$ long. Median lobe triangular, broad at base, tapering towards apex, bluntly rounded at apex; gonopore situated at apex, widely semicircular. Parameres longer than median lobe; narrow at base, rounded and slightly angulate at apex. Phallobase small, slightly wider than long.

\section{Remarks}

The species is only known from three historical specimens and the types had not been re-examined since the original description. We are here clarifying the identity of the species based on the examination of the types (see the redescription above) and an additional specimen. The species seems very rare, probably because of its distribution in lowland coastal areas from Maharashtra to Kerala, which are nowadays affected by high human population and high pollution. Additional research is needed to reveal whether the species is still present.

\section{Biology}

Unknown.

\section{Distribution}

Only known from coastal areas in northern Kerala (Mahé) and in Maharashtra (Mumbai).

Coelostoma (s. str.) fallaciosum Orchymont, 1936 Fig. 4A-K

Coelostoma fallaciosum Orchymont, 1936: 19.

Coelostoma (s. str.) fallaciosum - Hansen 1999: 244 (assigned to Coelostoma s. str.). - Hebauer 2002: 28 (faunistics); 2006: 8 (faunistics).

\section{Differential diagnosis}

Among Indian Coelostoma without pubescent mesofemora, C. fallaciosum may be recognized by its relatively large body size (resembling that of $C$. stultum and $C$. bhutanicum), simple abdominal apex 
without emargination or stout setae (with emargination and stout setae in both latter species) and with a typical aedeagus with subapical gonopore and strongly asymmetrical apex of the paramere. In the morphology of male genitalia it also resembles $C$. aeneolum; see under that species for diagnosis.

\section{Material examined}

\section{Holotype}

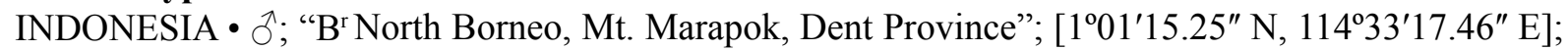
[694 m a.s.1.]; "Collector G. leg."; IRSNB.

\section{Other material}

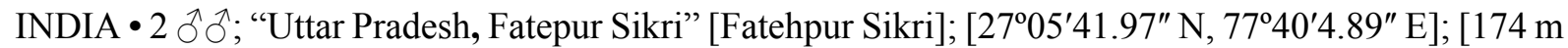
a.s.1.]; 21 Oct. 1997; J. Štastný leg.; NMPC.

NEPAL • 1 spec.; Annapurna, Pokhara, W of Phewa river + lake; [28 $15^{\prime} 50.88^{\prime \prime}$ N, 83 $83^{\circ} 58^{\prime} 18.66^{\prime \prime}$ E]; 800-850 m a.s.1.; 14-15 Oct. 2003; J. Schmidt leg.; NMPC.

\section{Published records}

NEPAL: Bheri Prov., Nepalgunj, 2802'59" N 8136'56" E (Hebauer 2002); Annapurna Prov., Pokhara, $\mathrm{W}$ of Phewa river and lake (Hebauer 2006).

\section{Redescription}

Form AND COLOUR. Body length 5.6-6.4 mm (holotype $5.7 \mathrm{~mm}$ ), body width 3.0-3.6 mm (holotype $3.3 \mathrm{~mm}$ ). Body oval in dorsal view, moderately convex in lateral view. Head black, pronotum and elytra dark brown to black with slightly paler margins; ventral surface uniformly dark brown, abdomen with pale spot at sides of each ventrite; appendages paler distally; mouthparts and antennal club brown.

HEAD. Dorsal punctation moderately dense, consisting of simple punctures without associated ridges; surface between punctures smooth; few trichobothria present. Anterior margin of clypeus arcuate. Eyes large, interocular distance ca $4 \times$ the width of one eye in dorsal view; eye emarginate anteriorly. Labrum moderately sclerotized, largely exposed anterior of clypeus, dark brown dorsally, sinuate on anterior margin. Antenna with 9 antennomeres, club loosely segmented. Second maxillary palpomere moderately broad.

Prothorax. Pronotum bisinuate anteriorly, anterolateral corners obtuse; posterior margin almost straight, posterolateral corners rounded. Anterior and lateral margins with distinct bead not extending to posterior margin. Pronotal punctation moderately dense, slightly coarser than on head, consisting of simple punctures without associated ridges; surface between punctures smooth. Prosternum straight on anterior margin, weakly carinate mesally, anterior portion of carina not raised.

Mesothorax. Elytral punctation moderately dense and coarse, similar to that on pronotum, consisting of punctures without transverse ridges. Series of punctures absent. Sutural stria weakly impressed, present in apical two thirds. Mesoventral plate $1.1 \times$ as long as wide, arrowhead-shaped, bluntly pointed anteriorly, posteriorly widely attached to metaventrite.

Metathorax. Metaventrite raised medially, median elevation bare, remaining median surface with sparse regular setae; lateral portions densely pubescent. Anterior metaventral process narrowly projecting between mesocoxae; posterior process bifid. Wings well-developed (macropterous).

Legs. Profemur with dense pubescence except in apical fifth; mesofemur and metafemur with sparsely arranged short setae only. 
AвDOMEn. All ventrites densely pubescent. First ventrite without carina. Posterior margin of last ventrite entire, without stout spines mesally.

Aedeagus (Fig. 4J-K). $1.0 \mathrm{~mm}$ long. Median lobe triangular, broad at base, tapering towards apex, bluntly rounded at apex; gonopore situated near apex, widely rounded. Parameres slightly longer than median lobe; pointed at apex, sinuate on outer margin. Phallobase small, slightly longer than wide.

\section{Biology}

Aquatic species, in Japan and Taiwan reported to inhabit shallow, well-vegetated pools (Liu et al. 2020; Nakajima et al. 2020). The biology of the specimens from the Indian subcontinent is unknown; all examined specimens were collected at light.

\section{Distribution}

A widespread species, so far recorded from Nepal (Hebauer 2002, 2006), northern India (this paper), Vietnam (Hansen 1999), southern China (Jia et al. 2014), Taiwan (Jia et al. 2014; Liu et al. 2020), Japan
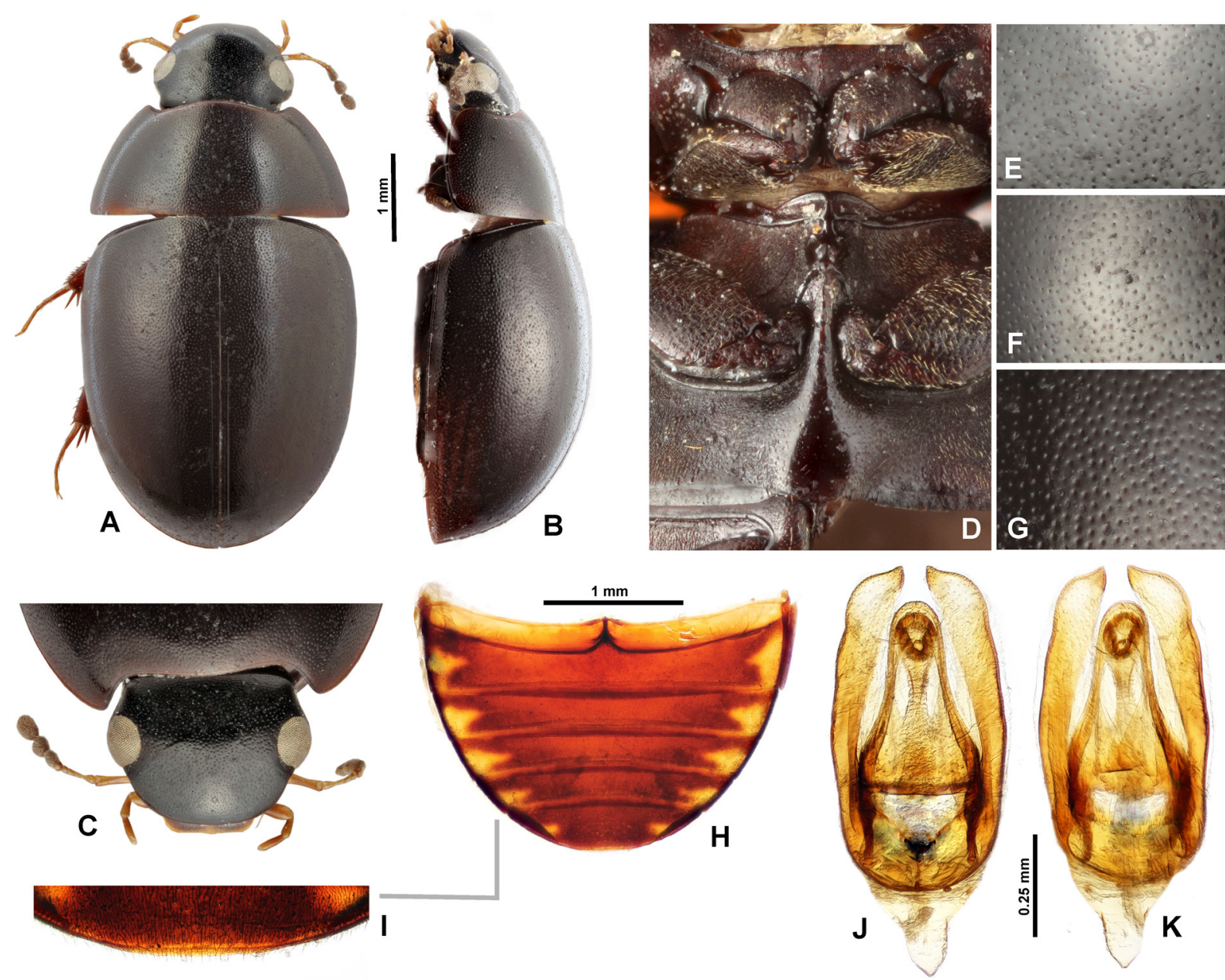

Fig. 4. Coelostoma (s. str.) fallaciosum Orchymont, 1936, ô specimen from India: Fatepur Sikri (NMPC). A. Dorsal habitus. B. Lateral habitus. C. Head in dorsal view. D. Thorax in ventral view. E. Dorsal punctation of head. F. Dorsal punctation of pronotum. G. Dorsal punctation of elytron. H. Abdominal ventrites. I. Detail of abdominal apex. J-K. Aedeagus: ventral (J) and dorsal (K). 
(Ishigaki and Iriomote Isl.; Hayashi 2008; Nakajima et al. 2020), Singapore (Hendrich et al. 2004), Borneo (Orchymont 1936) and Sumatra (Hansen 1999). First report for India.

Coelostoma (s. str.) nostocinum sp. nov. urn:lsid:zoobank.org:act:B069E8DC-6096-4292-B70D-93D6C5CB7337

Fig. $5 \mathrm{~A}-\mathrm{K}$

\section{Differential diagnosis}

Coelostoma nostocinum sp. nov. is characterized by smaller body size, by which it especially resembles C. vividum. Its male genitalia with the triangular median lobe easily distinguish it from all species except C. fallaciosum and C. aeneolum. The species may be distinguished from $C$. fallaciosum by its much shorter median lobe (compared to parameres) with straight lateral margins (concave in C. fallaciosum) and wider apex, and by the more or less symmetrically pointed apex of the paramere (strongly asymmetrical in C. fallaciosum). Coelostoma nostocinum sp. nov. is very similar to C. aeneolum, but may be distinguished from it by its (1) smaller body size $(3.5-4.5 \mathrm{~mm}$, compared to $4.6 \mathrm{~mm}$ in C. aeneolum), (2) larger aedeagus ( $0.7 \mathrm{~mm}$, compared to $0.4 \mathrm{~mm}$ in C. aeneolum), (3) relatively longer apodemes of the median lobe (longer than half of the length of the apical triangular part of the median lobe, compared to much shorter than half the length in C. aeneolum) and (4) paramere distinctly concave on outer margin subapically and pointed apically (compared to evenly arcuate on whole outer margin and more less rounded apically in C. aeneolum).

\section{Etymology}

The species name refers to the finding of the holotype of this species in association with Nostoc Vaucher ex Bornet \& Flahault (see Biology).

\section{Material examined}

\section{Holotype}

INDIA - ${ }^{7}$; "GOA province, $30 \mathrm{~km} \mathrm{~S}$ of MARGAO (Madgaon), Palolem env., INDIA 2002 exped;

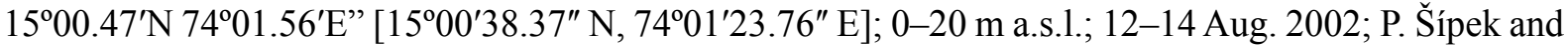
M. Fikáček leg; found in Nostoc-like algae; NMPC.

\section{Paratypes}

INDIA - Goa $\bullet 11$ specs; same collection data as for holotype; NMPC $\bullet 2$ specs; same collection data as for holotype; BMNH • $1 \mathrm{spec}$; same collection data as for holotype; UASB $01923074 \cdot 1 \mathrm{spec}$; same collection data as for holotype; ZSI • 3 specs; " $30 \mathrm{~km} \mathrm{~S}$ of Margao, Palolem env.; $15^{\circ} 00.47^{\prime} \mathrm{N}$,

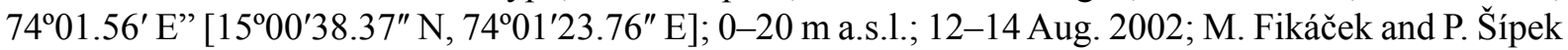
leg.; NMPC. - Maharashtra • 1 O, 33 specs; "4 km W of Lonavala, Bushi dam env." [Bhushi dam]; [18 $45^{\prime} 22.31^{\prime \prime} \mathrm{N}, 7^{\circ} 24^{\prime} 32.95^{\prime \prime}$ E]; 500 m a.s.1.; 24-28 Oct. 2005; J. Bezděk leg.; at light; NMPC • 3 specs; same collection data as for preceding; SMNS • 1 o, 1 spec.; "4 km S of Lonavala, Bushi dam env." [Bhushi dam]; [18 $43^{\prime} 24.35^{\prime \prime} \mathrm{N}, 7^{\circ} 23^{\prime} 49.43^{\prime \prime}$ E]; 500 m a.s.1.; 12-15 Oct. 2005; J. Bezděk leg.; NMPC • 1 spec.; same collection data as for preceding; NCBS BL020 2 ๙ิ $\hat{\jmath}, 3$ specs; Lonavala, $80 \mathrm{~km}$ E of Bombay; [1845'21.96" N, 73²4'32.40" E]; [630 m a.s.1.]; 13 Sep. 1991; R. Schuh leg.; NHMW. Karnataka • 1 spec.; Udipi distr., E of Bhatkal, Kollur; [13⒌'48.71" N, 7448'37.46" E]; [80 m a.s.1.]; 26-29 May 2006; Z. Kejval leg.; UASB 01923075. - Kerala • 6 specs; Cardamon Hills, 50 km NW of

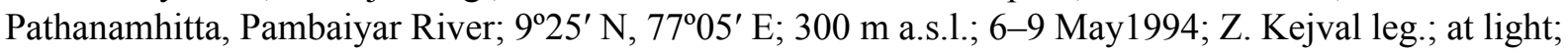
NHMW $\bullet 1$ spec.; same collection data as for preceding; NMPC. 


\section{Description}

Form AND COLOUR. Body length $3.3-4.5 \mathrm{~mm}$ (3.8 mm in holotype), body width $2.2-2.5 \mathrm{~mm}$ (2.4 mm in holotype). Body oval in dorsal view, moderately convex in lateral view. Head black, dark brown clypeus; pronotum and elytra uniformly dark brown to black; ventral surface pale to dark brown. Femora and tarsi yellowish brown, tibia dark reddish brown, tarsi pale brown. Mouth parts and antennae yellowish, antennal club brown.

HEAD. Dorsal punctation dense, consisting of simple punctures without associated ridges; trichobothria present; surface between punctures smooth. Anterior margin of clypeus non-arcuate. Eyes large, interocular distance ca $4.0 \times$ the width of one eye in dorsal view; eye emarginate anteriorly. Labrum moderately sclerotized, largely exposed anterior of clypeus. Antenna with 9 antennomeres, club loosely segmented. Second maxillary palpomere markedly wide.

Prothorax. Pronotum bisinuate anteriorly, anterolateral corners obtuse; posterior margin moderately bisinuate, posterolateral corners rectangular. Anterior and lateral margins with distinct bead not extending to posterior margin. Pronotal punctation finer than on head, consisting of simple punctures
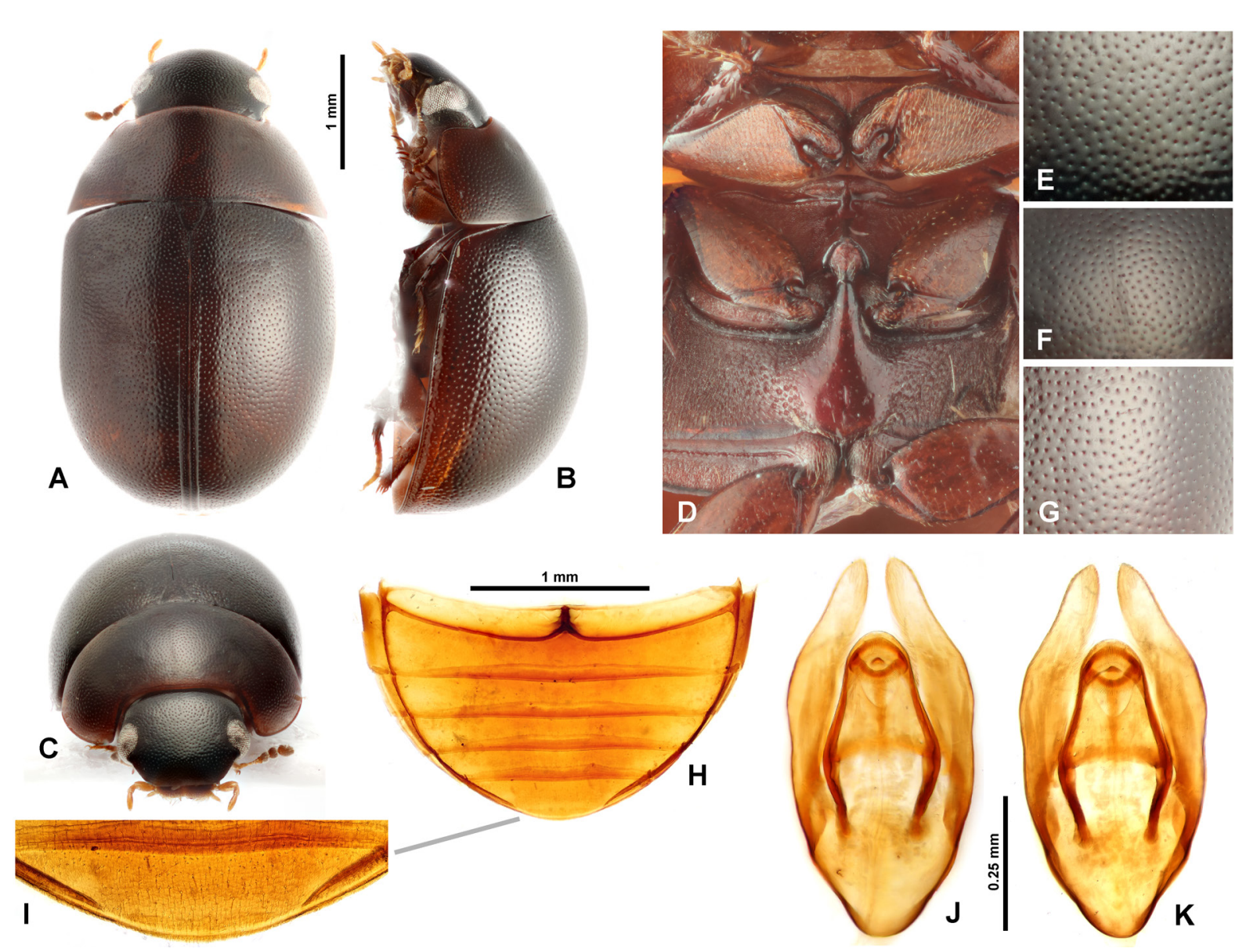

Fig. 5. Coelostoma (s. str.) nostocinum sp. nov. A. Dorsal habitus. B. Lateral habitus. C. Frontal view. D. Thorax in ventral view. E. Dorsal punctation of head. F. Dorsal punctation of pronotum. G. Dorsal punctation of elytron. H. Abdominal ventrites. I. Detail of abdominal apex. J-K. Aedeagus: ventral (J) and dorsal (K). Photographs based on: A-G. Paratype from Lonavala, Bhushi dam (NMPC). H-K. Holotype, $\widehat{\jmath}$ (NMPC). 
without associated ridges; surface between punctures smooth. Prosternum nearly straight on anterior margin, gently carinate mesally.

MESOTHORAX. Elytral punctation dense and moderately coarse, consisting of punctures without transverse ridges. Weakly developed series of impressed punctures present along suture and laterally. Sutural stria well impressed, present in apical half, extends beyond middle; lateral elytral margins with sculpture. Mesoventral plate as long as wide, arrowhead-shaped, bluntly pointed anteriorly, posteriorly widely attached to metaventrite.

Metathorax. Metaventrite raised medially, completely glabrous on median elevation, lateral portions pubescent. Anterior metaventral process narrowly projecting between mesocoxae; posterior process bifid. Wings well-developed (macropterous).

Legs. Profemur with dense pubescence except in apical fifth; mesofemur and metafemur with sparsely arranged short setae only.

AвDOMEn. All ventrites densely pubescent. First ventrite without carina. Posterior margin of last ventrite entire, without stout spines mesally.

AedeAgus (Fig. 5J-K). $0.7 \mathrm{~mm}$ long. Median lobe broad at base, slightly tapering towards widely rounded apex; gonopore situated at apex, widely semicircular. Parameres longer than median lobe; weakly arcuate on outer margin, narrowed in apical fourth; apex bluntly pointed; inner margin of parameres with long setae. Phallobase small, slightly wider than long.

\section{Variation}

Specimens from Maharashtra are slightly smaller than those from more southern areas. The aedeagus varies slightly in the shape of the parameres, the apical part of which is slightly wider in the specimens from Kerala; in all other aspects these specimens agree with those from Goa and hence we consider them conspecific.

\section{Remarks}

Coelostoma nostocinum sp. nov. and C. aeneolum are very similar in all characters including the morphology of the male genitalia, and both species seem to have very similar (and overlapping) distribution ranges. We were hence working with the hypothesis that they may be conspecific for some time, with the observed variation in body size and aedeagus morphology being an intraspecific variation. The examination of all available material, however, indicates that this is not the case, and that we really have two distinct morphotypes without intermediate characters: the species with larger body and smaller aedeagus with more or less rounded apices of parameres (C. aeneolum) and the smaller species with larger aedeagus with narrower and apically pointed paramere (C. nostocinum sp. nov.). Based on the material examined, both morphotypes are constant in the characters listed in the differential diagnosis across the distribution range (i.e., from Maharashtra to Kerala in both). For these reasons, we are treating them as separate species, with the smaller species described here as C. nostocinum sp. nov.

\section{Biology}

The specimens from Goa were collected under 'balls' of Nostoc blue-green algae growing on wet sandy places on rock cliffs at the sea coast. Specimens from Maharashtra were collected at light.

\section{Distribution}

Only known from the western coast of India and adjacent parts of the Western Ghats Mts, from Maharashtra to Kerala. 
Coelostoma (s. str.) lyratum sp. nov.

urn:1sid:zoobank.org:act:6E05380A-D3AA-410E-A974-D1CED984068A

Fig. 6A-K

\section{Differential diagnosis}

The species is easily recognized based on its aedeagus which resembles those of $C$. bhutanicum and C. stultum in its apically situated gonopore and parallel-sided median lobe. In contrast to both latter species, the outer margin of the parameres in strongly bisinuate in C. lyratum sp. nov. (in contrast to a nearly continuously arcuate outer margin in C. bhutanicum and C. stultum) and the abdominal apex is simple, without emargination and stout setae.

\section{Etymology}

The species name refers to the lyriform shape of the aedeagus; adjective.

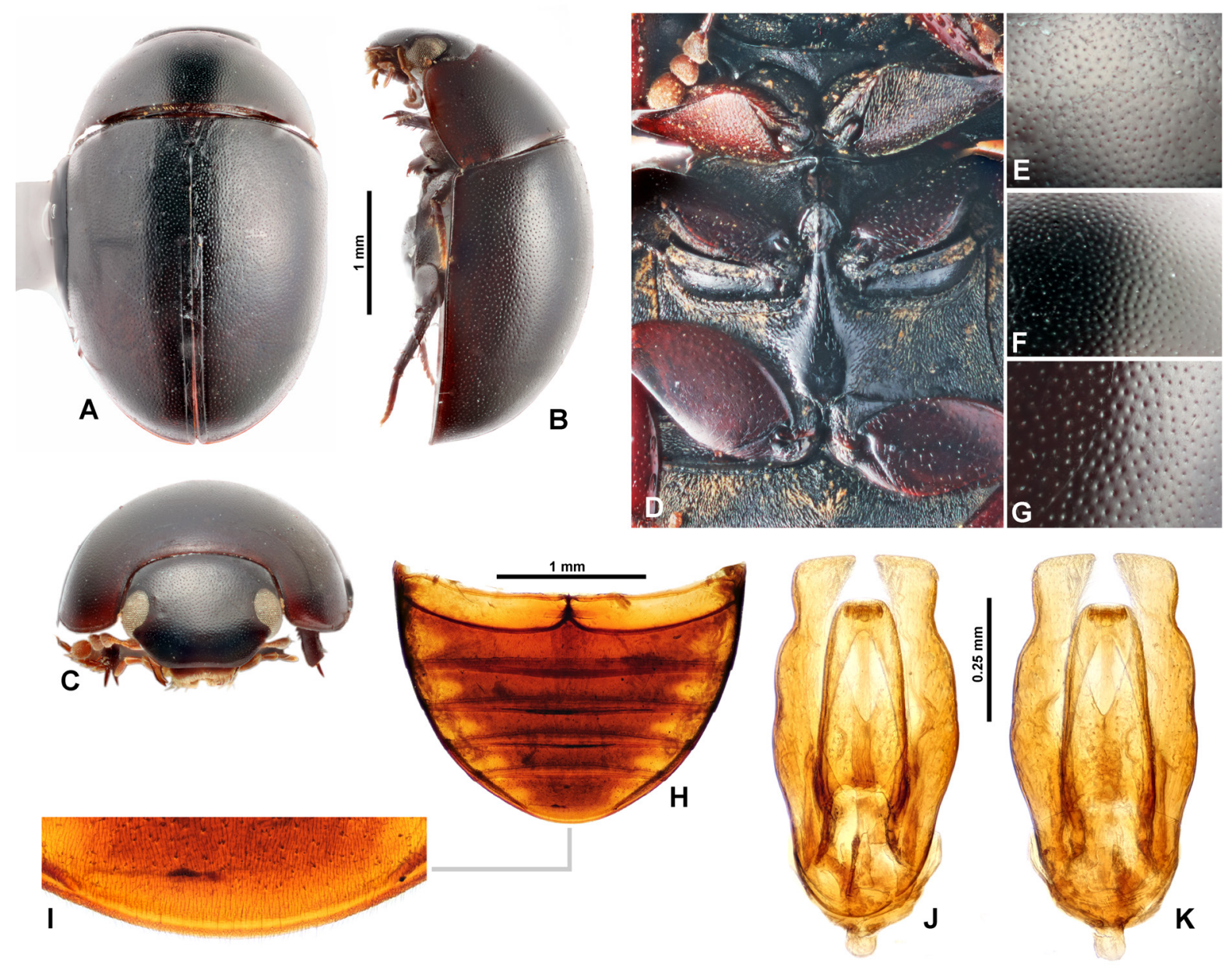

Fig. 6. Coelostoma (s. str.) lyratum sp. nov., holotype, $\widehat{\jmath}$ (NMPC). A. Dorsal habitus. B. Lateral habitus. C. Frontal view. D. Thorax in ventral view. E. Dorsal punctation of head. F. Dorsal punctation of pronotum. G. Dorsal punctation of elytron. H. Abdominal ventrites. I. Detail of abdominal apex. J-K. Aedeagus: ventral (J) and dorsal (K). 


\section{Type material}

Holotype

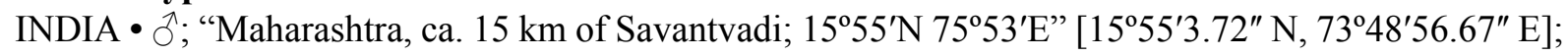
ca 40 m a.s.1.; 22 May 2006; Z. Kejval leg.; riverside; NMPC.

\section{Paratypes}

INDIA $\bullet$ Maharashtra $\bullet 3$ specs; same collection data as for holotype; NMPC $\bullet 2$ specs; same collection data as for holotype; BMNH $\bullet 1$ spec.; same collection data as for holotype; SMNS $\bullet 1$ spec.; same collection data as for holotype; ZSI 2 specs; same collection data as for holotype; NCBS-BL018-019 - 2 specs; same collection data as for holotype; UASB 01923068-69.

\section{Description}

Form AND COLOUR. Body length 4.2-4.7 mm (holotype $4.5 \mathrm{~mm}$ ), body width $2.7-3.1 \mathrm{~mm}$ (holotype $3.0 \mathrm{~mm}$ ). Body narrowly oval in dorsal view, moderately convex in lateral view. Head black, reddish brown near clypeus and anterior to eyes; pronotum and elytra uniformly dark brown to black with slightly paler margins, ventral surface blackish brown, legs reddish brown. Mouthparts and antennae pale brown, antennal club brown.

HEAD. Dorsal punctation dense, consisting of simple punctures without associated ridges; trichobothria present; surface between punctures smooth. Anterior margin of clypeus arcuate, indistinctly emarginated medially. Eyes large, interocular distance ca $4.0 \times$ the width of one eye in dorsal view; eye emarginate anteriorly. Labrum moderately sclerotized, largely exposed anterior of clypeus. Antenna with 9 antennomeres, club loosely segmented. Second maxillary palpomere moderately broad.

Prothorax. Pronotum bisinuate anteriorly, anterolateral corners obtuse; posterior margin moderately bisinuate, posterolateral corners rectangular. Anterior and lateral margins with distinct bead not extending to posterior margin. Pronotal punctation denser and finer than on head, consisting of simple punctures without associated ridges; surface between punctures smooth. Prosternum straight on anterior margin, weakly carinate mesally.

Mesothorax. Elytral punctation dense and moderately coarse, consisting of punctures without transverse ridges. Series of impressed punctures absent. Sutural stria impressed, present in apical two thirds. Mesoventral plate as long as wide, arrowhead-shaped, bluntly pointed anteriorly, posteriorly widely attached to metaventrite.

Metathorax. Metaventrite raised medially, median part sparsely pubescent except posterior third and anterior part, which are bare; lateral portions pubescent. Anterior metaventral process narrowly projecting between mesocoxae; posterior process bifid. Wings well-developed (macropterous).

Legs. Profemur with dense pubescence except in apical fifth; mesofemur and metafemur with very sparsely arranged short setae only.

AвDOMEN. All ventrites densely pubescent. First ventrite without carina. Posterior margin of last ventrite entire, without stout spines mesally.

Aedeagus (Fig. 6J-K). $0.84 \mathrm{~mm}$ long. Median lobe of nearly the same width throughout; apex roundly cut off; gonopore situated at apex, widely semicircular. Parameres slightly longer than median lobe; heavily tri-sinuate on outer margin; apex acute at inner margin, rounded laterally. Phallobase small, slightly wider than long. 


\section{Biology}

Unknown. The labels of the type specimens indicate that they were found at the riverside.

\section{Distribution}

Known from the type locality in southern Maharashtra.

Coelostoma (s. str.) vitalisi Orchymont, 1923

Fig. 7A-K

Coelostoma vitalisi Orchymont, 1923a: 418.

Coelostoma (s. str.) vitalisi - Orchymont 1925: 269 (faunistics); 1928: 57 (catalogue); 1936: 27 (faunistics). - Jia et al. 2017: 118 (faunistics).

\section{Differential diagnosis}

Coelostoma vitalisi is easy to recognize based on its aedeagus, with a very wide median lobe with a very large subapical gonopore. Thanks to the unique genital morphology, it cannot be confused with any other species of the genus.

\section{Material examined}

\section{Holotype}

Not examined.

\section{Other material}

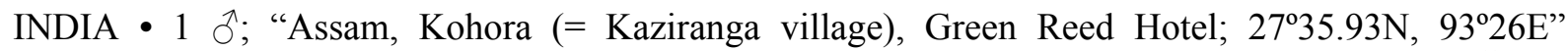
[265' $21.81^{\prime \prime}$ N, 9324'44.07" E]; [1000 m a.s.1.]; 16-18 Apr. 2008; Fikáček, Podskalská and Šípek leg.; at light; NMPC.

\section{Published records}

NEPAL: Narayani Sauraha, bank of Rapti River (Hebauer 2002; Jia et al. 2017); Seti distr., Bajhang, on the way from Chainpur to Sagu Bagar (Jia et al. 2017); valley of Rapti river, Jhawani (Jia et al. 2017); Narayani Prov., Sauraha SW Royal Chitwan Nat. Park (Hebauer 2002); Kathmandu, Baneshwar (Hebauer 2002). INDIA: Uttarakhand: Dehradun (Orchymont 1936). Chhattisgarh: 'Barway' [= Barway mission, Chainpur env., see Fikáček et al. 2012] (Orchymont 1925, 1936). Bihar: Pusa (Orchymont 1923b). Jharkhand: Mandar (Orchymont 1925). Kerala: 'Calicut' [= Kozhikode] (Orchymont 1936). SRI LANKA: without specified locality (Orchymont 1928, 1936) [specimens reported by Orchymont (1925) as C. vitalisi from India: West Bengal ('Bengal' and 'Calcutta') were found to belong to C. vividum by Orchymont (1936)].

\section{Description}

Form AND COLOUR. Body length 4.0-4.9 mm, body width $2.5-2.9 \mathrm{~mm}$. Body oval in dorsal view, moderately convex in lateral view. Head black; pronotum and elytra uniformly black to dark brown with slightly paler margins; ventral surface uniformly dark brown. Tarsi pale brown. Mouthparts and antennae yellowish, antennal club brown.

HEAD. Dorsal punctation dense, consisting of simple punctures, few punctures at posterior-most portion with associated ridges; trichobothria present; surface between punctures smooth. Anterior margin of clypeus gently arcuate. Eyes large, interocular distance ca $4.3 \times$ the width of one eye in dorsal view; eye emarginate anteriorly. Labrum moderately sclerotized, largely exposed anterior of clypeus, sinuate 
on anterior margin, brown. Antenna with 9 antennomeres, club loosely segmented. Second maxillary palpomere moderately broad.

Prothorax. Pronotum bisinuate anteriorly, anterolateral corners obtuse; posterior margin moderately bisinuate, posterolateral corners rectangular. Lateral margin with very indistinct sculpture; anterior and lateral margins with distinct bead not extending to posterior margin. Pronotal punctation similar to that on head, consisting of simple punctures without associated ridges; surface between punctures smooth. Prosternum straight on anterior margin, very weakly carinate mesally, anterior portion raised, producing tooth-like process seen in lateral view.

Mesothorax. Elytral punctation dense and moderately coarse, similar to that on pronotum, consisting of punctures without transverse ridges. Series of punctures absent. Sutural stria impressed, present in apical half. Mesoventral plate $1.1 \times$ as long as wide, arrowhead-shaped, bluntly pointed anteriorly, posteriorly widely attached to metaventrite.

Metathorax. Metaventrite raised medially, posterior third and anterior portion of median elevation bare, remaining median surface with sparse regular setae; lateral portions densely pubescent. Anterior
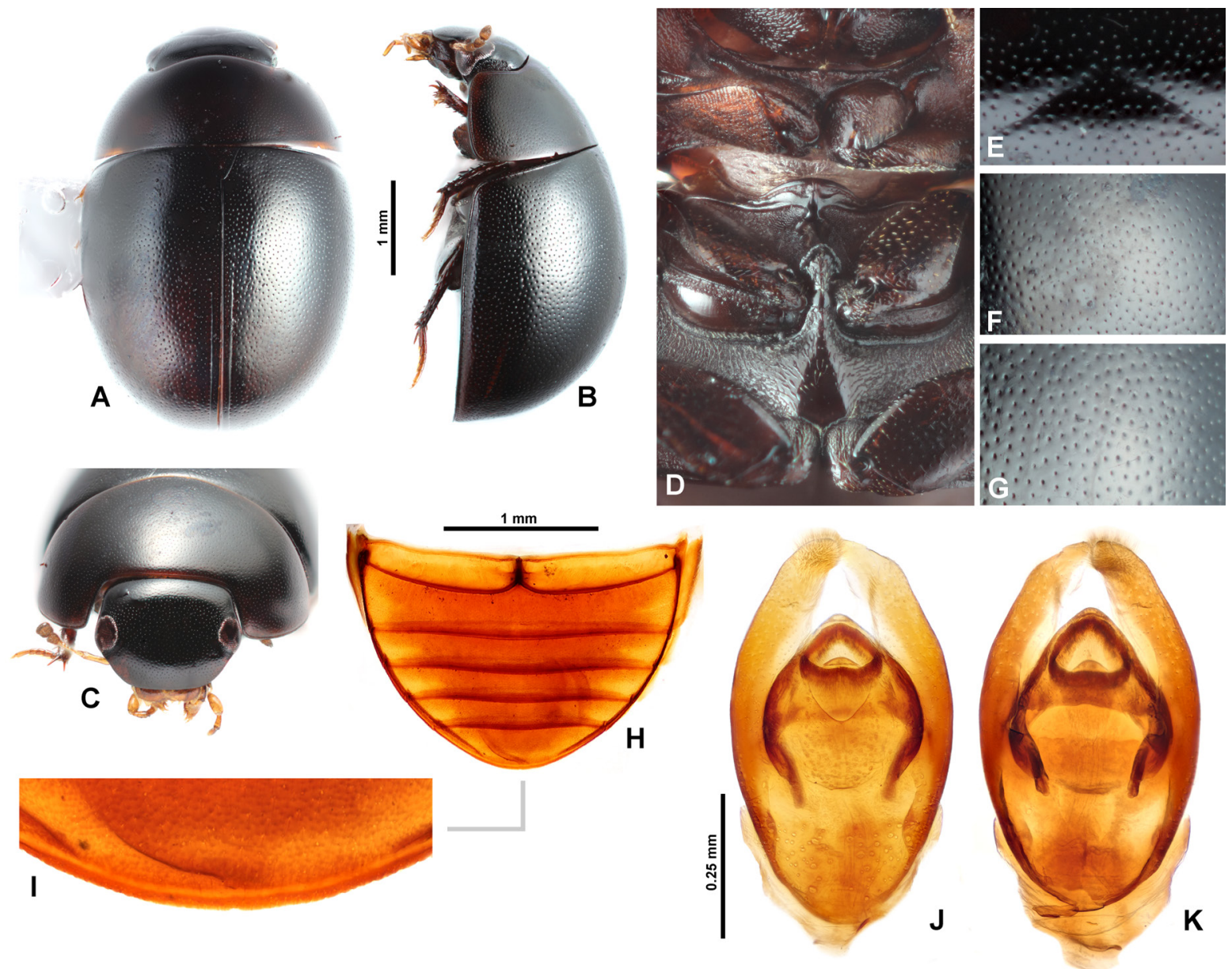

Fig. 7. Coelostoma (s. str.) vitalisi Orchymont, 1923, o specimen from Assam: Kohora (NMPC). A. Dorsal habitus. B. Lateral habitus. C. Frontal view. D. Thorax in ventral view. E. Dorsal punctation of head. F. Dorsal punctation of pronotum. G. Dorsal punctation of elytron. H. Abdominal ventrites. I. Detail of abdominal apex. J-K. Aedeagus: ventral (J) and dorsal (K). 
metaventral process narrowly projecting between mesocoxae; posterior process bifid. Wings welldeveloped (macropterous).

LEGS. Profemur with dense pubescence except in apical fifth; mesofemur with sparsely arranged stout setae only, metafemur with sparse pubescence.

AвDOMEn. All ventrites densely pubescent. First ventrite without carina. Posterior margin of last ventrite entire, without stout spines mesally.

Aedeagus (Fig. 7J-K). $0.75-0.85 \mathrm{~mm}$ long. Median lobe triangular, broad at middle, tapering towards apex; gonopore situated at apex, widely semicircular. Parameres longer than median lobe; rounded or obtusely pointed at apex. Phallobase small, slightly wider than long.

\section{Biology}

Aquatic species, Nakajima et al. (2020) reported it from shallow wetlands in lowland to hilly areas. Most specimens available in the collections were collected at light.

\section{Distribution}

Widespread species, known from Nepal (Jia et al. 2017), India (Orchymont 1925, 1936; this paper), Sri Lanka (Orchymont 1936), Cambodia, Thailand, Vietnam (Jia et al. 2017), Indonesia (Borneo, Java, Sumatra; Orchymont 1923a, 1925), Malaysia (Sabah; Orchymont 1925), Singapore (Orchymont 1925; Jia et al. 2014), southern China (Jia et al. 2014), Taiwan (Liu et al. 2020) and Japan (Minoshima 2017; Nakajima et al. 2020).

\section{Coelostoma (s. str.) vividum Orchymont, 1936}

Fig. $8 \mathrm{~A}-\mathrm{K}$

Coelostoma vividum Orchymont, 1936: 28.

Coelostoma (s. str.) vividum - Jia et al. 2017: 118 (faunistics).

\section{Differential diagnosis}

Coelostoma vividum is easy to recognize due to its small body size and the aedeagus with the apically strongly narrowed median lobe.

\section{Material examined}

\section{Paratype}

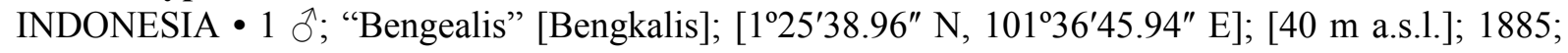
Maindron leg.; IRSNB.

\section{Other material}

INDIA - Assam • 1 đ, 2 specs; "Kohora (= Kaziranga village), Green Reed Hotel; 27035.93N 9326E"

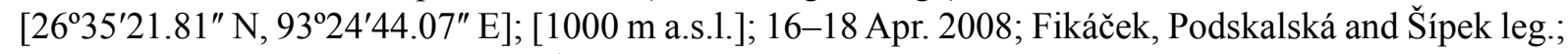
at light; NMPC. - Meghalaya 1 O ${ }^{\curvearrowright}, 6$ specs; W Garo Hills, Bagmara; $25^{\circ} 11.5$ N, $90^{\circ} 38.5$ E; ca $100 \mathrm{~m}$ a.s.l.; 15-21 May 1996; Jendek and Šauša leg.; NHMW.

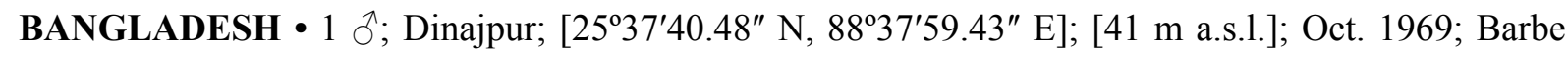
leg.; NMPC. 


\section{Published records}

PAKISTAN: Khyber Pakhtunkhwa: Madyan (Jia et al. 2017). NEPAL: Mahakali distr., Kanchanpur Mahendranagar (Jia et al. 2017). INDIA: West Bengal: 'Bengal' (Orchymont 1936), Kolkata (Orchymont 1936).

\section{Description}

Form AND COLOUR. Body length 3.4-4.1 mm, body width 2.1-2.3 mm. Body oval in dorsal view, moderately convex in lateral view. Head black; pronotum and elytra uniformly black to dark brown with slightly paler margins; ventral surface uniformly dark brown. Tarsi pale brown. Mouthparts and antennae yellowish, antennal club brown.

HEAD. Dorsal punctation dense, consisting of coarse simple punctures, a few punctures with associated ridges in posterior-most region; trichobothria present; surface between punctures smooth. Anterior margin of clypeus gently arcuate. Eyes large, interocular distance ca $4.0 \times$ the width of one eye in dorsal view; eye emarginate anteriorly. Labrum moderately sclerotized, largely exposed anterior of clypeus, pale brown in coloration. Antenna with 9 antennomeres, club loosely segmented. Second maxillary palpomere moderately broad.
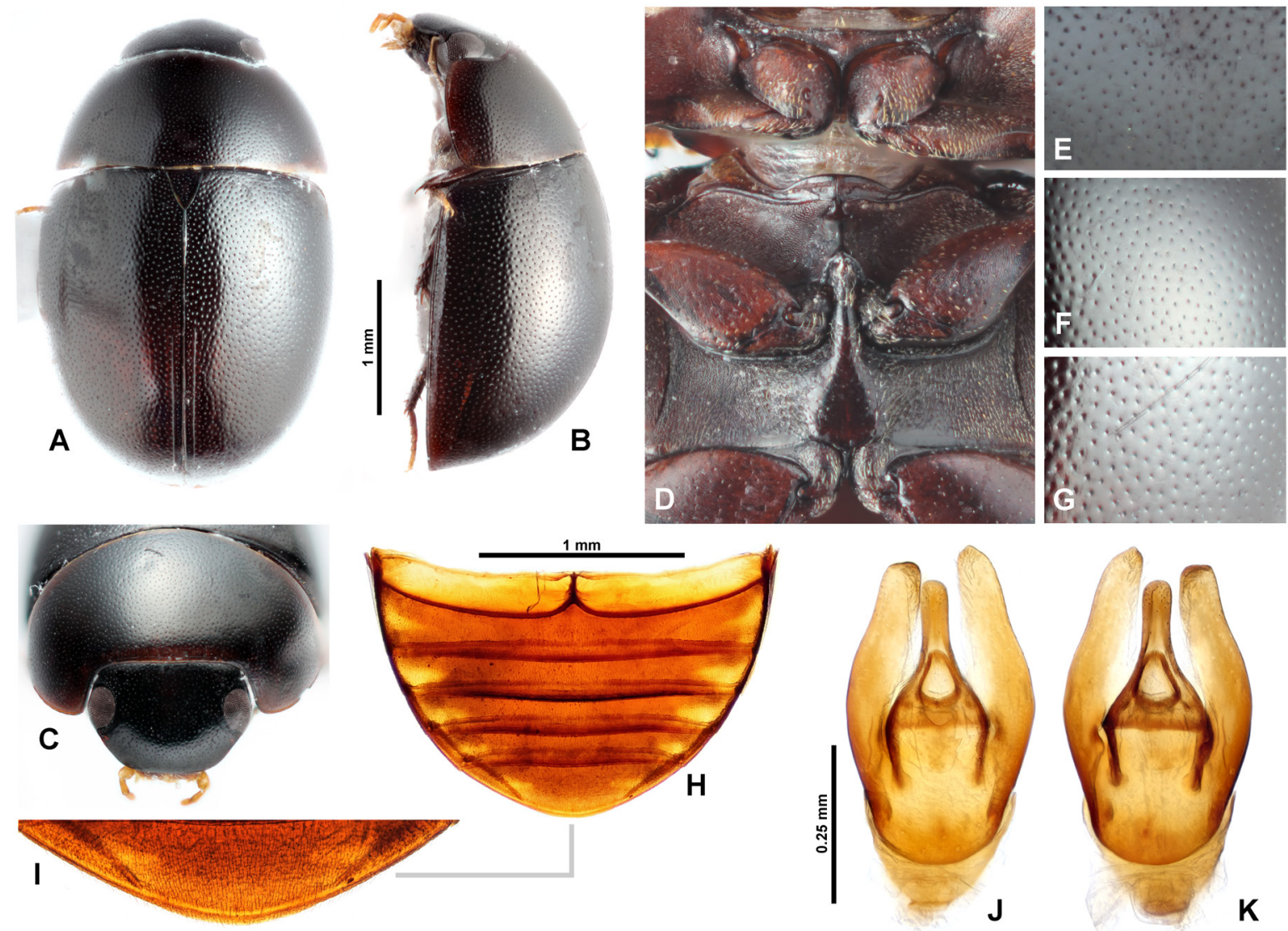

Fig. 8. Coelostoma (s. str.) vividum Orchymont, 1936, specimens from Assam: Kohora (NMPC). A. Dorsal habitus. B. Lateral habitus. C. Frontal view. D. Thorax in ventral view. E. Dorsal punctation of head. F. Dorsal punctation of pronotum. G. Dorsal punctation of elytron. H. Abdominal ventrites. I. Detail of abdominal apex. J-K. Aedeagus: dorsal (J) and ventral (K). 
Prothorax. Pronotum bisinuate anteriorly, anterolateral corners obtuse; posterior margin moderately bisinuate, posterolateral corners rectangular. Lateral margin with very indistinct sculpture; anterior and lateral margins with distinct bead not extending to posterior margin. Pronotal punctation sparser and finer than on head, consisting of simple punctures without associated ridges; surface between punctures smooth. Prosternum straight on anterior margin, carinate mesally, anterior portion of carina raised, producing tooth-like process seen in lateral view.

MESOTHORAX. Elytral punctation dense and moderately coarse, consisting of punctures without transverse ridges. Series of punctures absent. Sutural stria impressed, present in apical half. Mesoventral plate $1.1 \times$ as long as wide, arrowhead-shaped, bluntly pointed anteriorly, posteriorly widely attached to metaventrite.

Metathorax. Metaventrite raised medially, surface glabrous with sparse regular setae; lateral portions densely pubescent. Anterior metaventral process narrowly projecting between mesocoxae; posterior process bifid. Wings well-developed (macropterous).

Legs. Profemur with dense pubescence except in apical fifth; mesofemur with sparsely arranged stout setae only; metafemur with sparse pubescence.

АвDомen. All ventrites densely pubescent. First ventrite without carina. Posterior margin of last ventrite entire, without stout spines mesally.

Aedeagus (Fig. 8J-K). $0.6 \mathrm{~mm}$ long. Median lobe triangular, broad at base, tapering towards narrowly spatulate apex; gonopore situated basally, widely semicircular. Parameres slightly longer than median lobe; broad, weakly pointed at apex, inner margin with setae. Phallobase small, slightly wider than long.

\section{Biology}

Unknown. Published specimens were all collected at light.

\section{Distribution}

Widespread species, so far recorded from northern Pakistan (Jia et al. 2017), Nepal (Jia et al. 2017), India (Orchymont 1936; this paper), Bangladesh (this paper), Cambodia (Jia et al. 2017), southern China (Jia et al. 2017) and Indonesia (Java, Sumatra, Borneo; Orchymont 1936).

\section{Coelostoma (Holocoelostoma) bhutanicum Jayaswal, 1972}

Fig. 9A-K

Coelostoma sulcata $\mathrm{Pu}, 1963: 77$, possible synonym [needs confirmation, see comments below].

Coelostoma (Holocoelostoma) bhutanicum Jayaswal, 1972: 409.

Coelostoma (Holocoelostoma) bhutanicum - Hebauer 2002: 28 (faunistics).

\section{Differential diagnosis}

Coelostoma bhutanicum is easy to recognize from most other Coelostoma species by the apical gonopore and widely parallel-sided median lobe; in these characters it resembles only C. stultum and C. lyratum sp. nov. From $C$. lyratum sp. nov. it differs by the evenly arcuate outer face of the paramere and by the abdominal apex bearing a shallow emargination armed with stout setae. In both these characters it agrees with $C$. stultum, from which it is only recognizable by an examination of the male genitalia: the aedeagus of $C$. bhutanicum is more sclerotized and seemingly more 'robust' than that of C. stultum when examined quickly. The main difference is in the form of the median lobe, which has strongly 
sclerotized lateral margins in C. bhutanicum. This causes the median lobe to be of nearly the same width from base to apical fifth, from which it abruptly narrows (in contrast, the median lobe is narrowing from base to ca midlength and is of more or less the same width in the apical half in C. stultum). The more sclerotized margins in C. bhutanicum also affect the 3D form of the median lobe, which is distinctly spoon-like (best seen when the aedeagus is slightly rotated when examined).

\section{Material examined}

Type material

Holotype not examined. [Types are deposited in the Zoological Survey in Kolkata but were not studied.]

\section{Other material}

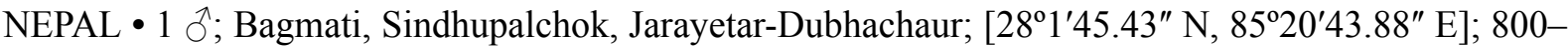
1600 m a.s.1.; 2 Jun. 1989; F. Hebauer determined as C. stultum; M. Brancucci leg.; NMPC.

INDIA - Rajastan [Rajasthan] - $1 \hat{\jmath}, 1$; ; Alwar district, $30 \mathrm{~km} \mathrm{~N}$ of Dausa, Gola-ka-bas village; $27^{\circ} 05^{\prime} 31^{\prime \prime}$ N, $76^{\circ} 18^{\prime} 47^{\prime \prime}$ E; 359 m a.s.1.; 24-28 Mar. 2004; P. Šípek and L. Šejnohová leg.; NMPC. -

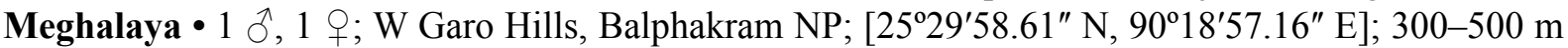
a.s.l.; 22-27 May 1996; Jendek and Šauša leg.; NHMW • 1 §ో; W Garo Hills, Bagmara; 25⒒5' N, $90^{\circ} 26.5^{\prime}$ E; ca 100 m a.s.1.; 19-21 May 1996; Jendek and Šauša leg.; NHMW. - Kerala • 1 ó; Cardamon Hills, $50 \mathrm{~km}$ NW of Pathanamhitta, Pambaiyar River; $9^{\circ} 25^{\prime}$ N, $7^{\circ} 05^{\prime}$ E; 300 m a.s.1.; 5-9 May 1994; Z. Kejval leg.; NHMW.

\section{Published records}

BHUTAN: Ganga lakha (Jayaswal 1972). INDIA: Uttarakhand: Nainital (Jayaswal 1972). Records published from Nepal by Hebauer (2002) need confirmation, as our examination of a few specimens identified by F. Hebauer revealed that he often confused C. bhutanicum with C. stultum.

\section{Redescription}

FORM AND COLOUR. Body length 4.7-5.8 mm, body width 2.8-3.5 mm. Body widely oval in dorsal view, moderately convex in lateral view. Head black; pronotum and elytra uniformly dark brown to black with slightly paler margins; ventral surface uniformly reddish brown. Tarsi pale brown. Mouthparts and antennae yellowish brown, antennal club brown.

HEAD. Dorsal punctation dense, consisting of simple punctures without associated ridges; trichobothria present; surface between punctures smooth. Anterior margin of clypeus arcuate. Eyes large, interocular distance ca $2.8 \times$ the width of one eye in dorsal view; eye emarginate anteriorly. Labrum moderately sclerotized, largely exposed anterior of clypeus. Antenna with 9 antennomeres, club loosely segmented. Second maxillary palpomere moderately broad.

Prothorax. Pronotum bisinuate anteriorly, anterolateral corners obtuse; posterior margin moderately bisinuate, posterolateral corners rectangular. Anterior and lateral margins with distinct bead not extending to posterior margin. Pronotal punctation slightly finer than on head, consisting of simple punctures without associated ridges; surface between punctures smooth. Prosternum straight on anterior margin, weakly elevated mesally, anterior portion of carina not very elevated.

Mesothorax. Elytral punctation dense and moderately coarse, consisting of punctures without transverse ridges. Series of impressed punctures absent. Sutural stria weakly impressed, present in apical half. Mesoventral plate as long as wide, arrowhead-shaped, bluntly pointed anteriorly, posteriorly widely attached to metaventrite. 

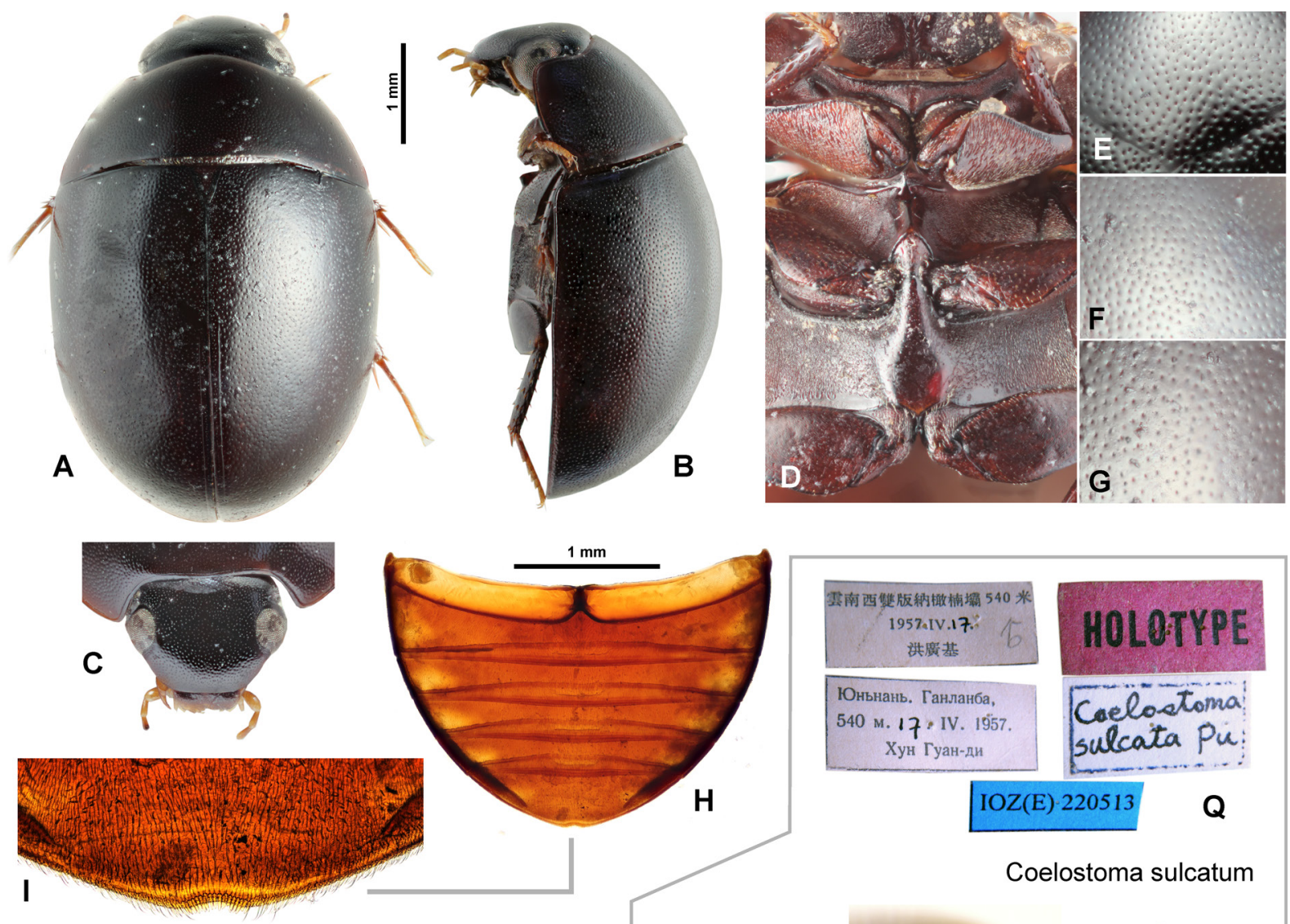

м. 17 , IV. 1957

IOZ(E) 220513

Caelostoma sulcata Pu:
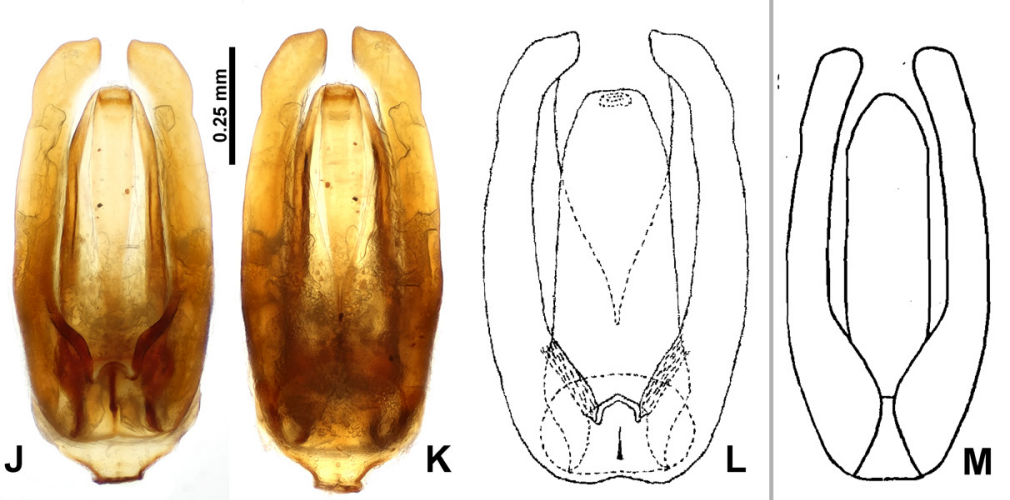

Coelostoma sulcatum
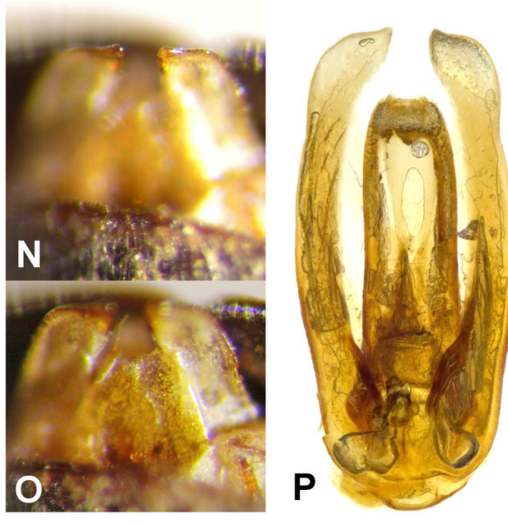

Fig. 9. Coelostoma (Holocoelostoma) bhutanicum Jayaswal, 1972 (A-L) and C. (H.) sulcatum Pu, 1963 (M-Q). A-K. C. bhutanicum, non-type specimen from India: Rajasthan, Alwar (NMPC). A. Dorsal habitus. B. Lateral habitus. C. Head. D. Thorax in ventral view. E. Dorsal punctation of head. F. Dorsal punctation of pronotum. G. Dorsal punctation of elytron. H. Abdominal ventrites. I. Detail of abdominal apex. J-K. Aedeagus: dorsal $(\mathrm{J})$ and ventral $(\mathrm{K})$. L. Illustration of the aedeagus of the paratype of C. bhutanicum by Jayaswal (1972). M. Aedeagus illustration from the description of $C$. sulcatum in $\mathrm{Pu}$ (1963). N-O. Apex of the aedeagus of the holotype of C. sulcatum. P. Aedeagus of the paratype of C. sulcatum from Yunnan: Jingdong. Q. Labels of the holotype of C. sulcatum. 
Metathorax. Metaventrite raised medially, posterior third and anterior of median elevation bare, lateral portions pubescent. Anterior metaventral process narrowly projecting between mesocoxae; posterior process bifid. Wings well-developed (macropterous).

LEGS. Profemur with dense pubescence except in apical fifth; mesofemur with sparsely arranged stout setae only; metafemur with very sparse pubescence.

ABDOMEN. All ventrites densely pubescent. First ventrite without carina. Posterior margin of last ventrite emarginate, with stout spines mesally.

Aedeagus (Fig. 9J-K). 1.0-1.1 mm long. Median lobe nearly parallel-sided, not widened basally, slightly narrowing in apical fifth; gonopore totally apical, widely oval in shape. Parameres longer than median lobe; apex rectangular at inner margin, not projecting inwards, rounded laterally. Phallobase small, wider than long.

\section{Variation}

The apical part of the median lobe is less narrowed in specimens from Taiwan (see Liu et al., 2020), but otherwise the aedeagus morphology seems very constant across the range in this species.

\section{Identity of $\boldsymbol{C}$. bhutanicum and synonymies}

The identity of this species was long unclear, and many taxonomists considered it as a possible synonym of $C$. stultum, although this opinion was never published because of the inaccessibility of the types. The comparison of the aedeagus of the specimens from northern India examined here with the drawing by Jayaswal (1972) leaves little doubt that both refer to the same species: Jayaswal's (1972) drawing (Fig. 9L) shows the typical shape of the median lobe having the same width along the whole length except for the apical fifth. The slightly wider form illustrated on Jayaswal's (1972) drawing is likely caused by the fact that the genitalia were slide-mounted.

Jia et al. (2014) illustrated the male genitalia of two specimens identified as C. stultum from China (from Guangdong and Xizang), which both clearly show the strongly sclerotized lateral margins of the median lobe and the shape of the median lobe corresponding to those in C. bhutanicum. This indicates that (1) Jia et al. (2014) mixed the two species, and C. bhutanicum clearly occurs in China, and (2) the status of C. sulcatum $\mathrm{Pu}, 1963$ as a synonym of C. stultum proposed by Jia et al. (2014) is incorrect. Coelostoma sulcatum was described from specimens from Yunnan, Xishuanbanna (type locality) and Jindong, and the illustration by $\mathrm{Pu}$ (1963) shows the typical form of the median lobe present in C. bhutanicum (Fig. 9M). We hence suspect that C. sulcatum Pu, 1963 and C. bhutanicum Jayaswal, 1972 may refer to the same species. Martin Fikáček examined the types of $C$. sulcatum (the holotype from Xishunagbanna and a paratype from Jindong) briefly during his visit to Beijing in 2010 and took photographs of the holotype, with the abdominal apex showing a slightly protruding aedeagus (Fig. 9N-O), and of the completely dissected aedeagus of the paratype (Fig. 9P). The aedeagus of the paratype shows the median lobe with clearly sclerotized lateral margins, but it is rather narrow and not abruptly narrowing at the apex as it is typical for C. bhutanicum; this may be because the aedeagus is slightly deformed by dehydration. The apex of the aedeagus of the holotype shows the typical shape of the parameres present in both C. bhutanicum and C. stultum but absent from the illustration by $\mathrm{Pu}$ (1963) and also clearly shows the narrowing apex of the median lobe, further indicating that the shape of the median lobe of the paratype may be a deformation. The dissection of the holotype, remounting the aedeagus of the paratype or the examination of fresh material from Xishuanbanna would be necessary to understand the identity of C. sulcatum correctly and to confirm its synonymy with $C$. bhutanicum, which we are hypothesizing here. This synonymy would affect the nomenclature, since $C$. sulcatum would become a valid name and C. bhutanicum its junior synonym. However, we refrain from proposing the formal synonymy until the 
identity of $C$. sulcatum can be completely clarified, in order to prevent even more confusion about the species concepts within the subgenus Holocoelostoma.

\section{Biology}

Aquatic species; in Taiwan, the specimens were collected at the sides of ponds (among plant roots) and of running water (under stones and in mud) (Liu et al. 2020). The specimens examined by us were likely collected at light.

\section{Distribution}

Due to the confusion of this species with $C$. stultum, the distribution of $C$. bhutanicum requires more study. The occurrence is so far confirmed in Bhutan, Nepal and northern India (Jayaswal 1972, this paper), in China (based on photographs provided by Jia et al. 2014), in Taiwan (Liu et al. 2020) and Japan (Watanabe \& Minoshima 2020).

\section{Coelostoma (Holocoelostoma) stultum (Walker, 1858)}

Fig. 10A-M

Hydrobius stultus Walker, 1858: 209.

Coelostoma stultum - Zaitzev 1908: 404 (catalogue). — Knisch 1924: 113 (catalogue).

Coelostoma (Holocoelostoma) stultum - Orchymont 1923b: 2 (faunistics); 1928: 56 (catalogue); 1936: 17 (faunistics). — Mouchamps 1958: 3 (transfer to Holocoelostoma). — Satô 1979: 49 (faunistics). Hebauer 2000: 6 (faunistics); 2002: 31 (faunistics); 2006: 8 (faunistics). — Darilmaz \& Ahmed 2015: 10 (faunistics). — Jia et al. 2017: 118 (faunistics).

\section{Differential diagnosis}

Large species, easy to recognize from all other Coelostoma species except C. bhutanicum by the combination of the widely parallel-sided median lobe with apical gonopore and emarginate abdominal apex with stout setae. From C. bhutanicum it may be only recognized by the morphology of the median lobe of the aedeagus, which is wide basally, gradually narrowing to ca midlength and more less of the same width in apical half. In contrast to C. bhutanicum, C. stultum does not have strongly sclerotized lateral margins of the median lobe and the median lobe is not spoon-like in form.

\section{Material examined}

Lectotype (here designated)

SRI LANKA • +; “Ceylon”; [752'23.80" N, 8046'18.52" E]; [243 m a.s.1.]; BMNH.

\section{Other material}

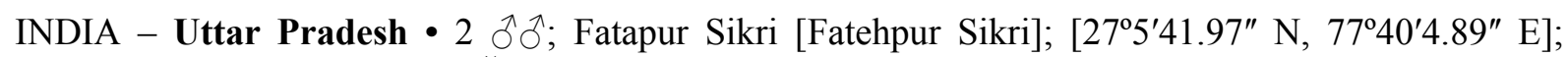
[174 m a.s.1.]; 31 Oct. 1997; J. Št’astný leg.; NMPC. - Rajasthan • 1 ô, 28 specs; Bharatpur, Keoladeo National Park and around; $27^{\circ} 12.42^{\prime}$ N, $77^{\circ} 30.48^{\prime}$ E; 220 m a.s.1.; 31 Aug.-5 Sep. 2002; M. Fikáček and P. Śípek leg.; NMPC • 3 specs; same collection data as for preceding; NCBS-BL022-024 3 specs; same collection data as for preceding; UASB $01923080-82 \cdot 2$ specs; same collection data as for

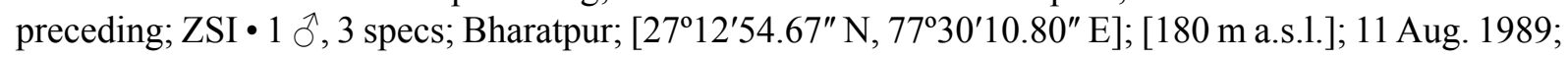
A. Riedel leg; NHMW. - Goa 1 万; " $30 \mathrm{~km} \mathrm{~S}$ of Margao (= Madgaon), Palolem env.; $15^{\circ} 00.47^{\prime}$ N,

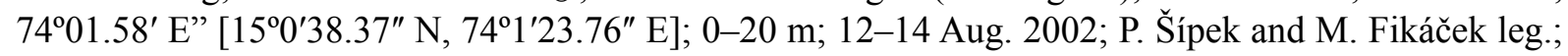
NMPC. - Assam • 1 ก, 1 o ; "Kohora (Kaziranga village) at Green Reed hotel; 26 $35^{\prime}$ N, $93^{\circ} 26^{\prime}$ E"

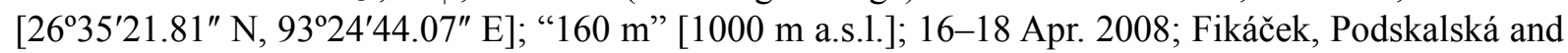

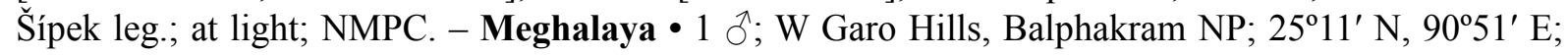


300-500 m a.s.1.; 22-27 May 1996; Jendek and Šauša leg.; NHMW • 1 đ̊; W Garo Hills, Bagmara; $25^{\circ} 11.5^{\prime}$ N, 90³8.5' E; ca 100 m a.s.1.; 18-21 May 1996; Jendek and Šauša leg.; NHMW.

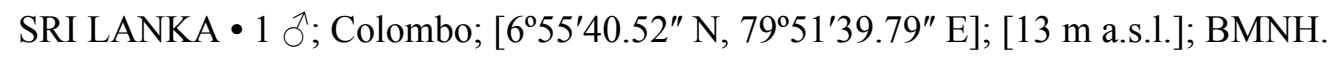

\section{Published records}

All published records of $C$. stultum from the Indian subcontinent need re-examination, as they very likely include misidentified C. bhutanicum.

\section{Description}

FORM AND COLOUR. Body length $3.8-5.2 \mathrm{~mm}$, body width $2.6-3.3 \mathrm{~mm}$. Body oval in dorsal view, moderately convex in lateral view. Head black; pronotum and elytra uniformly dark brown; ventral surface uniformly reddish brown. Tarsi pale brown. Mouthparts and antennae yellowish brown, antennal club brown.

HeAD. Dorsal punctation dense, consisting of simple punctures without associated ridges; trichobothria present; surface between punctures smooth. Anterior margin of clypeus arcuate. Eyes large, interocular distance ca $3.3 \times$ the width of one eye in dorsal view; eye emarginate anteriorly. Labrum moderately sclerotized, largely exposed anterior of clypeus. Antenna with 9 antennomeres, club loosely segmented. Second maxillary palpomere moderately broad.

Prothorax. Pronotum bisinuate anteriorly, anterolateral corners obtuse; posterior margin moderately bisinuate, posterolateral corners rectangular. Anterior and lateral margins with distinct bead not extending to posterior margin. Pronotal punctation sparser and finer than on head, consisting of simple punctures without associated ridges; surface between punctures smooth. Prosternum slightly projecting mesally on anterior margin, carinate mesally, anterior portion of carina very weakly elevated.

MESOTHORAX. Elytral punctation dense and moderately coarse, consisting of punctures without transverse ridges. Series of impressed punctures present along suture and laterally. Sutural stria weakly impressed, present in apical half. Mesoventral plate as long as wide, arrowhead-shaped, bluntly pointed anteriorly, posteriorly widely attached to metaventrite.

Metathorax. Metaventrite raised medially, posterior third and anterior of median elevation bare, lateral portions pubescent. Anterior metaventral process narrowly projecting between mesocoxae; posterior process bifid. Wings well-developed (macropterous).

LEGS. Profemur with dense pubescence except in apical fifth; mesofemur with sparsely arranged stout setae only; metafemur with very sparse pubescence.

ABdomen. All ventrites densely pubescent. First ventrite without carina. Posterior margin of last ventrite emarginate, with stout spines mesally.

Aedeagus (Fig. 10K-M). 0.8-1.0 mm long. Median lobe broad at base, slightly tapering towards apex; gonopore situated at apex but still directed dorsally, widely oval in shape. Parameres slightly longer than median lobe; apex rectangular at inner margin, not projecting inwards, rounded laterally. Phallobase small, wider than long.

\section{Variation}

The form of the median lobe differs slightly between the examined specimens from India and Sri Lanka and those from Taiwan and Japan (see Liu et al. 2020), but in all cases the median lobe is widest at the 
base and narrowed ca at mid-length. Additional studies are needed to understand whether this variation may represent a geographic variability of the species.

\section{Lectotype designation}

On the request to loan the type specimens from the Walker collection at BMNH, we received two specimens, both considered as syntypes. Both are females, but each of them belongs to a different species: the specimen labelled as cotype belongs to the subgenus Holocoelostoma based on the emarginated abdominal apex and mesofemora lacking dense pubescence; it agrees externally in all details
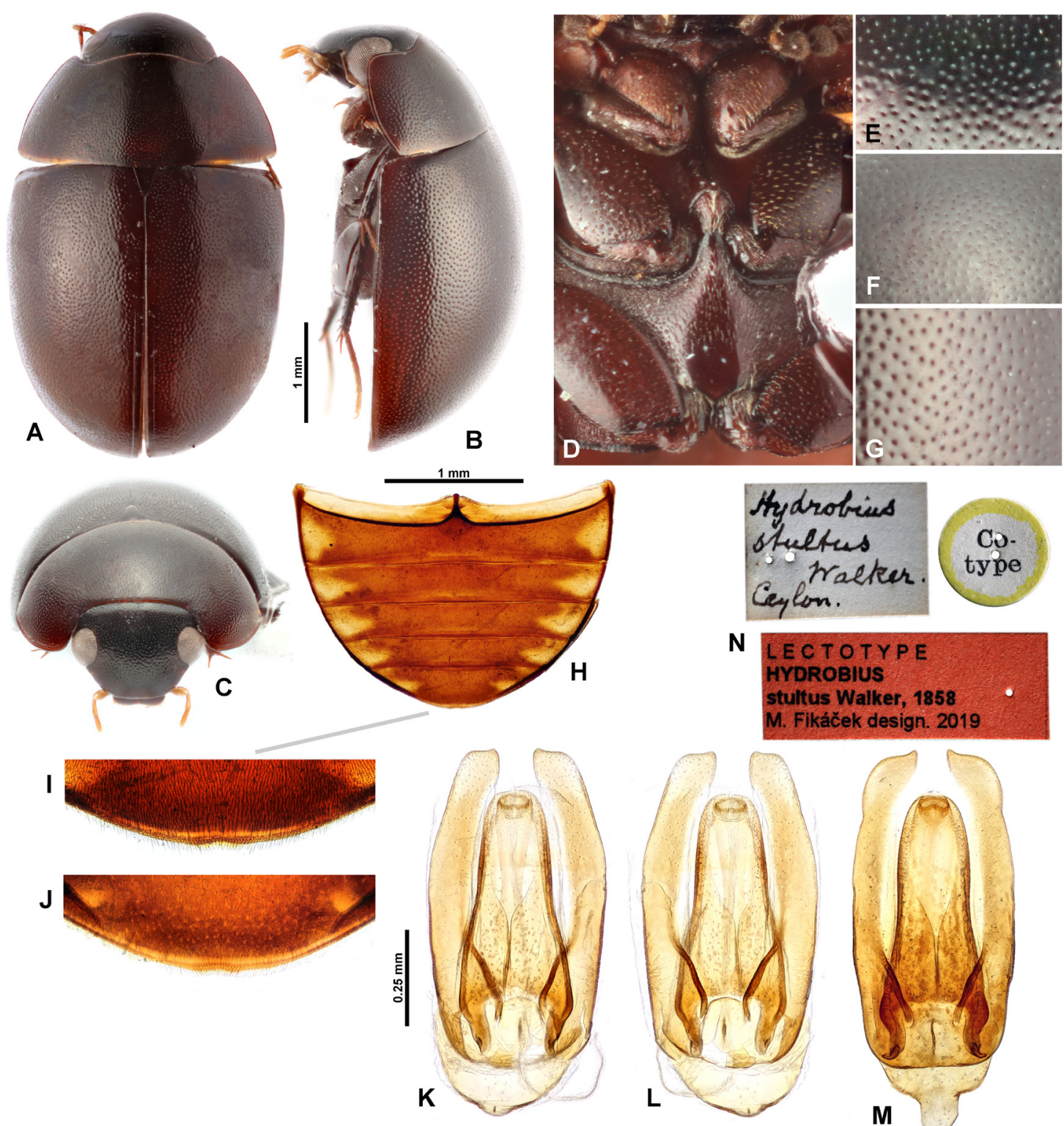

N LECTOTYPE HYOROBIUS stultus Walker, 1858 M. Fikáček design. 2019
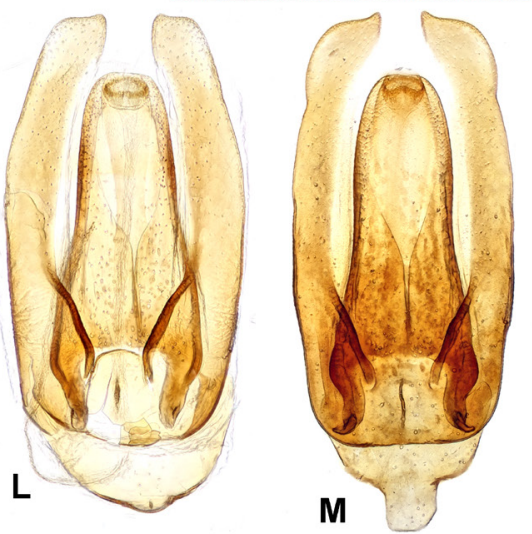

Fig. 10. Coelostoma (Holocoelostoma) stultum (Walker, 1858). A. Dorsal habitus. B. Lateral habitus. C. Head. D. Thorax in ventral view. E. Dorsal punctation of head. F. Dorsal punctation of pronotum. G. Dorsal punctation of elytron. H. Abdominal ventrites. I-J. Detail of abdominal apex. K-M. Aedeagus: dorsal $(\mathrm{K})$ and ventral $(\mathrm{L}-\mathrm{M})$. N. Labels of the lectotype. Specimens: A-I, K-L. Non-type specimens from Uttar Pradesh, Fatehpur Sikri, ô (NMPC). J, N. Lectotype, ㅇ (BMNH). M. Non-type specimen, $\hat{\jmath}$, from Sri Lanka: Colombo (BMNH). 
with a male specimen from Colombo, the genitalia of which are illustrated on Fig. 10M. The second specimen, labelled as type, has an emarginate abdominal apex and densely pubescent mesofemora, and hence belongs to the subgenus Lachnocoelostoma. To fix the current concept of $C$. stultum and of Holocoelostoma (of which C. stultum is the type species), we are therefore designating the first specimen as the lectotype.

\section{Biology}

Aquatic species; in Japan and Taiwan it inhabits vegetation-rich places with muddy bottoms, typically ponds, rice fields and river sides (Liu et al. 2020; Nakajima et al. 2020).

\section{Distribution}

Coelostoma stultum is reported as a very widespread species, extending from the Arabian Peninsula (Fikáček et al. 2010) to Japan (Hayashi 2008) and New Guinea (Hebauer 2001) (see Hansen 1999 for a summary), also recorded from the Mascarene Islands and Madagascar (Hebauer 2006). This distribution

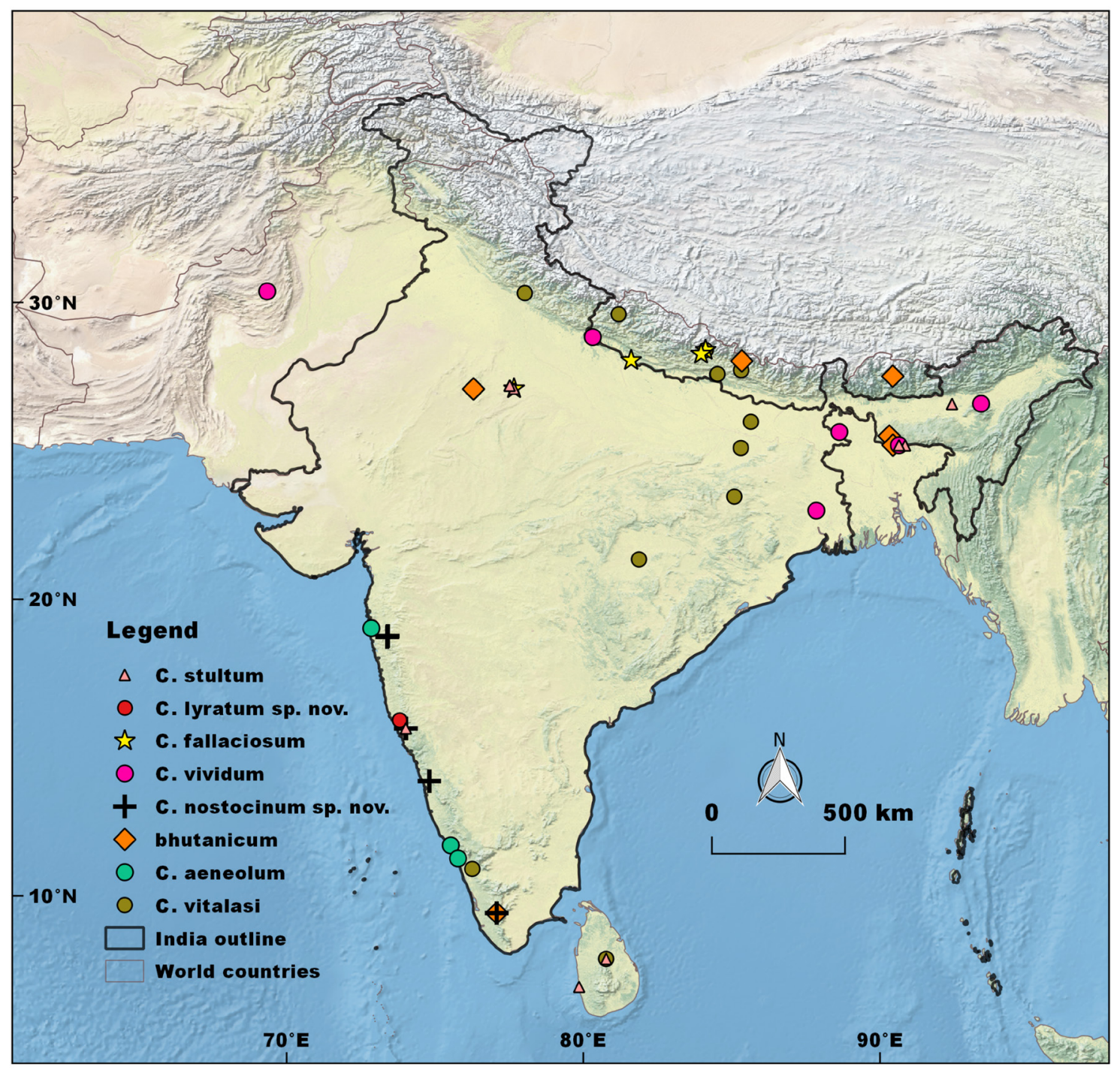

Fig. 11. Known distribution of the Coelostoma s. str. and Holocoelostoma species in the Indian subcontinent. 
is, however, surely partly based on misidentified specimens of C. bhutanicum, and needs revision. Based on the material examined for this study and published illustrations of male genitalia, we may confirm the species to occur in the following countries at present: United Arab Emirates (Fikáček et al. 2010), India (this paper), Srí Lanka (Walker 1858, this paper), Taiwan (Liu et al. 2020) and Japan (Hayashi 2008).

\section{Discussion}

The species diversity of the subgenera Coelostoma (s. str.) and Holocoelostoma in the Indian subcontinent is rather low ( 6 and 2 species, respectively), with 5 species being moreover very widespread across the whole Oriental Region (Fig. 11). In this respect the fauna of the Indian subcontinent corresponds, e.g., to the fauna of China, where 5 species of Coelostoma s. str. and two species of Holocoelostoma occur, all of them being widespread species (Jia et al. 2014, 2017; this paper). In contrast to the Chinese fauna, three species of the Indian subcontinent seem to be more local and likely endemic to the western coast of India ( $C$. aeneolum, $C$. nostocinum sp. nov. and C. lyratum sp. nov.). The relatively low species diversity of Coelostoma (s. str.) and Holocoelostoma in the Oriental Region seems to contrast with the available data on the subgenus Lachnocoelostoma, which contains a high number of species, many of which are local endemics (e.g., Jia et al. 2014, 2017, 2019; Liu et al. 2020). Habitat preferences of Coelostoma (s. str.) and Holocoelostoma species may be partly responsible for this pattern: all species of these two subgenera for which habitat data are available inhabit lowland standing waters. The only known exception is the finding of the above-described C. nostocinum sp. nov. in growths of Nostoc blue-green algae not associated with a nearby aquatic environment. In contrast, available data on the species of Lachnocoelostoma indicate a much wider spectrum of habitats, including the sides of running waters and wet rocks (Jia et al. 2014; Liu et al. 2020). Previous studies on aquatic beetles indicated that species of standing (lentic) waters tend to have larger ranges than species of running (lotic) waters (e.g., Ribera \& Vogler 2000). Available data would indicate a similar pattern for Oriental Coelostoma, although further studies are needed to test this assumption.

\section{Acknowledgements}

Sayali D. Sheth is grateful to the authorities of the National Museum, Prague, Czech Republic for providing facilities. Sayali is obliged to the Museum of Comparative Zoology, Harvard University, Massachusetts, USA for an Ernst Mayr travel grant to support her work at the museum and the University Grants Commission, Delhi, India for partial funding. Sayali is thankful to Emmanuel Arriaga-Varela, Matthias Seidel and Albert Hernandez for their help at the museum. Sayali thanks her colleagues and friends for their help. Hemant V. Ghate and Sayali acknowledge the authorities of Modern College and Abasaheb Garware college for support. The research activities of Martin Fikáček were supported by the Ministry of Culture of the Czech Republic (DKRVO 2019-2023/5.I.b, National Museum, 00023272). Last but not the least, the authors are grateful to Robert Angus for linguistic corrections of the manuscript.

\section{References}

Bloom D.D., Fikáček M. \& Short A.E.Z. 2014. Clade age and diversification rate variation explain disparity in species richness among water scavenger beetle (Hydrophilidae) lineages. PLoS ONE 9 (6): e98430. https://doi.org/10.1371/journal.pone.0098430

Darilmaz M.C. \& Ahmed Z. 2015. Aquatic Coleoptera from Pakistan: faunistic and zoogeographical contribution (Coleoptera: Gyrinidae: Dytiscidae: Hydrophilidae). Journal of Natural History 50 (3): 149-162. https://doi.org/10.1080/00222933.2015.1059515

Fikáček M. \& Liu H.-C. 2019. A review of Thysanarthria with description of seven new species and comments on its relationships to Chaetarthria (Hydrophilidae: Chaetarthriini). Acta Entomologica Musei Nationalis Pragae 59 (1): 229-252. 
Fikáček M., Gentili E. \& Short A.E.Z. 2010. Order Coleoptera, family Hydrophilidae. In: Harten A. van (ed.) Arthropod Fauna of the UAE 3: 135-165. Dar Al Ummah, Abu Dhabi.

Fikáček M., Jia F.-L. \& Prokin A. 2012. Review of the Asian species of the genus Pachysternum (Coleoptera: Hydrophilidae: Sphaeridiinae). Zootaxa 3219: 1-53. https://doi.org/10.11646/zootaxa.3219.1.1

Hansen M. 1991. The hydrophiloid beetles. Phylogeny, classification and a revision of the genera (Coleoptera: Hydrophilidae). Biologiske Skrifter 40: 1-367.

Hansen M. 1999. World Catalogue of Insects 2: Hydrophiloidea (s. str.) (Coleoptera). Apollo Books, Stenstrup, Denmark.

Hayashi M. 2008. Distributional records and ecological notes on aquatic Coleoptera of Shimane Prefecture, Part II. Bulletin of Hoshizaki Green Foundation 11: 93-102.

Hebauer F. 2000. Results of the Lund University Ceylon Expedition 1962. Hydrophilidae, with an updated Sri Lanka check list (Coleoptera: Hydrophilidae). Acta Coleopterologica 16 (2): 3-13.

Hebauer F. 2001. Beitrag zur Kenntnis der Hydrophilidae von Neuguinea. Ergebnisse der zoologischen Forschungsreisen von M. Balke and L. Hendrich nach West Neuguinea (Irian Jaya) in den Jahren 19901998 (Coleoptera: Hydrophilidae). Acta Coelopterogica 17 (1): 3-72.

Hebauer F. 2002. Hydrophilidae of North India and Southern Himalaya (Coleoptera: Hydrophilidae). Acta Coleopterologica 18 (1): 3-72.

Hebauer F. 2006. Description of a new Coelostoma from China (Coleoptera: Hydrophilidae, Sphaeridiinae). Acta Coleopterologica 22 (1): 3-4.

Hendrich L., Balke M. \& Yang C.M. 2004. Aquatic Coleoptera of Singapore - Species richness, ecology and conservation. The Raffles Bulletin of Zoology 52 (1): 97-141.

Hortal J., de Bello F., Diniz-Filho J.A.F., Lewinsohn T.M., Lobo J.M. \& Ladle R.J. 2015. Seven shortfalls that beset large-scale knowledge of biodiversity. Annual Review of Ecology, Evolution, and Systematics 46: 523-549. https://doi.org/10.1146/annurev-ecolsys-112414-054400

Jayaswal K.P. 1972. On the two new species of the hydrophiloid beetles (Coleoptera: Hydrophilidae). Zoologischer Anzeiger 189: 409-412.

Jia F.-L., Aston P. \& Fikáček M. 2014. Review of the Chinese species of the genus Coelostoma Brullé, 1835 (Coleoptera: Hydrophilidae: Sphaeridiinae). Zootaxa 3887 (3): 354-376.

https://doi.org/10.11646/zootaxa.3887.3.4

Jia F.-L., Lin R.-C., Chan E., Skale A. \& Fikáček M. 2017. Two new species of Coelostoma Brullé, 1835 from China and additional faunistic records of the genus from the Oriental Region (Coleoptera: Hydrophilidae: Sphaeridiinae: Coelostomatini). Zootaxa 4232 (1): 113-122.

https://doi.org/10.11646/zootaxa.4232.1.8

Jia F.-L., Angus R.B. \& Bian D. 2019. Two new species of Coelostoma Brullé, 1835 from China (Coleoptera: Hydrophilidae: Sphaeridiinae). Aquatic Insects 40 (4): 291-299.

https://doi.org/10.1080/01650424.2019.1612072

Knisch, A. 1924. Hydrophilidae. In: Junk W. \& Schenkling S. (eds) Coleopterorum Catalogus. Vol. 14. part 79 . W. Junk, Berlin.

Liu H.-C., Hu F.-S. \& Fikáček M. 2020. Review of the genus Coelostoma of Taiwan with description of a new species (Coleoptera: Hydrophilidae). Acta Entomologica Musei Nationalis Pragae 60 (1): $155-162$.

Mani M.S. 1974. Ecology and Biogeography in India. W. Junk, The Hague. 
Minoshima Y. 2017. A new record of Coelostoma vitalisi d'Orchymont from Kyushu Island (Coleoptera, Hydrophilidae). Elytra, New Series 7 (1): 20.

Minoshima Y., Fikáček M., Gunter N. \& Leschen R. 2015. Larval morphology and biology of the New Zealand-Chilean genera Cylomissus Broun and Anticura Spangler (Coleoptera: Hydrophilidae: Rygmodinae). The Coleopterists Bulletin 69: 687-712. https://doi.org/10.1649/0010-065X-69.4.687

Minoshima Y.N., Seidel M., Wood J.R., Leschen R.A.B., Gunter N.L. \& Fikáček M. 2018. Morphology and biology of the flower-visiting water scavenger beetle genus Rygmodus (Coleoptera: Hydrophilidae). Entomological Science 21 (4): 363-384. https://doi.org/10.1111/ens.12316

Mittermeier R.A., Robles-Gil P., Hoffmann M., Pilgrim J.D., Brooks T.M., Mittermeier C.G., Lamoreux J.L. \& Fonseca G. 2005. Hotspots Revisited: Earth's Biologically Richest and Most Endangered Terrestrial Ecoregions. CEMEX, Mexico City.

Mouchamps R. 1958. Notes sur quelques Coelostoma (Brullé) (Coléoptères Hydrophilidae) principalement africains (12 $2^{\mathrm{me}}$ note). Bulletin de l'Institut royal des Sciences naturelles de Belgique 34 (41): $1-36$.

Myers N., Mittermeier R.A., Mittermeier C.G., da Fonseca G.A.B. \& Kent J. 2000. Biodiversity hotspots for conservation priorities. Nature 403: 853-858. https://doi.org/10.1038/35002501.

Nakajima J., Hayashi M., Ishida K., Kitano T. \& Hiroyuki Y. 2020. Aquatic Coleoptera and Hemiptera of Japan. Bun-ichi Sogo Shuppan, Tokyo.

d'Orchymont A. 1923a. Neue oder interessante Sphaeridiinen und Hydrophilinen der Malayischen Region. Treubia 3: 416-421.

d'Orchymont A. 1923b. Hydrophilidae of India (Col.). A list of the species in the collection of the Agricultural Research Institute at Pusa (Bihar). Memoirs of the Department of Agriculture in India 7: $1-12$.

d'Orchymont A. 1925. Contribution à l'étude des Hydrophilides III. Bulletin et Annales de la Société entomologique de Belgique 65: 261-295.

d'Orchymont A. 1928. Catalogue of Indian Insects. Part 14. Palpicornia. Government of India Central Publication Branch, Calcutta.

d'Orchymont A. 1936. Revision des Coelostoma (s. str.) non americains. Mémoires du Musée royal d'Histoire naturelle de Belgique 7 (2): 1-38.

$\mathrm{Pu}$ C. 1963. Results of the zoologico-botanical expedition to southwest China, 1955-1957 (Coleoptera, Hydrophilidae). Acta Entomologica Sinica 12: 77-82.

Régimbart M. 1903. Voyage de M. Maurice Maindron dans l'Inde méridionale (Mai à Novembre 1901) Dytiscides, Gyrinides et Palpicornes. Annales de la Société entomologique de France 72: 331-339.

Ribera I. \& Vogler A.P. 2000. Habitat type as a determinant of species range sizes: the example of loticlentic differences in aquatic Coleoptera. Biological Journal of the Linnean Society 71: 33-52.

https://doi.org/10.1111/j.1095-8312.2000.tb01240.x

Satô M. 1979. Ergebnisse der Bhutan-Expedition 1972 und Indien-Nepal-Expeditionen 1975-1977 des Naturhistorischen Museums in Basel. Coleoptera: Fam. Georissidae, Hydraenidae, Hydrophilidae und Ptilodactylidae. Entomologica Basiliensia 4: 43-67.

Sheth S.D., Ghate H.V. \& Hájek J. 2018. Copelatus Erichson, 1832 from Maharashtra, India, with description of three new species and notes on other taxa of the genus (Coleoptera: Dytiscidae: Copelatinae). Zootaxa 4459 (2): 235-260. https://doi.org/10.11646/zootaxa.4459.2.2 
Short A.E.Z. \& Fikáček M. 2013. Molecular phylogeny, evolution, and classification of the Hydrophilidae (Coleoptera). Systematic Entomology 38 (4): 723-752. https://doi.org/10.1111/syen.12024

Toussaint E.F.A. \& Short A. 2018. Transoceanic stepping-stones between Cretaceous waterfalls? The enigmatic biogeography of pantropical Oocyclus cascade beetles. Molecular Phylogenetics and Evolution 127: 416-428. https://doi.org/10.1016/j.ympev.2018.04.023

Walker F. 1858. Characters of some apparently undescribed Ceylon insects. Annals and Magazine of Natural History, Series 3, 2: 202-209. https://doi.org/10.1080/00222935808697009

Watanabe K. \& Minoshima Y.N. 2020. First record of Coelostoma bhutanicum Jayaswal, 1972 (Coleoptera: Hydrophilidae) from Japan. Japanese Journal of Systematic Entomology 26 (1): 151-152.

Zaitzev F.A. 1908. Catalogue des Coléoptères aquatiques des familles Dryopidae, Georyssidae, Cyathoceridae, Heteroceridae et Hydrophilidae. Horae Societatis entomologicae rossicae 38: 283-420.

Manuscript received: 17 April 2020

Manuscript accepted: 3 June 2020

Published on: 24 July 2020

Topic editor: Nesrine Akkari

Section editor: Max Barclay

Desk editor: Pepe Fernández

Printed versions of all papers are also deposited in the libraries of the institutes that are members of the EJT consortium: Muséum national d'histoire naturelle, Paris, France; Meise Botanic Garden, Belgium; Royal Museum for Central Africa, Tervuren, Belgium; Royal Belgian Institute of Natural Sciences, Brussels, Belgium; Natural History Museum of Denmark, Copenhagen, Denmark; Naturalis Biodiversity Center, Leiden, the Netherlands; Museo Nacional de Ciencias Naturales-CSIC, Madrid, Spain; Real Jardín Botánico de Madrid CSIC, Spain; Zoological Research Museum Alexander Koenig, Bonn, Germany; National Museum, Prague, Czech Republic.

\section{Supplementary File}

SM.01. List of specimens examined in DarwinCore format (.xls file). 